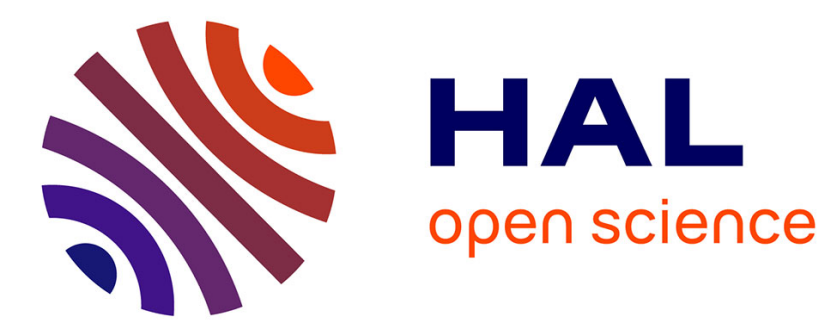

\title{
The use of pollen floras as a tool to estimate palaeoaltitude of mountains: The eastern Pyrenees in the Late Neogene, a case study \\ Jean-Pierre Suc, Séverine Fauquette
}

\section{- To cite this version:}

Jean-Pierre Suc, Séverine Fauquette. The use of pollen floras as a tool to estimate palaeoaltitude of mountains: The eastern Pyrenees in the Late Neogene, a case study. Palaeogeography, Palaeoclimatology, Palaeoecology, 2012, 321-322, pp.41-54. 10.1016/j.palaeo.2012.01.014 . hal-00676473

\section{HAL Id: hal-00676473 \\ https://hal.science/hal-00676473}

Submitted on 14 Jan 2014

HAL is a multi-disciplinary open access archive for the deposit and dissemination of scientific research documents, whether they are published or not. The documents may come from teaching and research institutions in France or abroad, or from public or private research centers.
L'archive ouverte pluridisciplinaire HAL, est destinée au dépôt et à la diffusion de documents scientifiques de niveau recherche, publiés ou non, émanant des établissements d'enseignement et de recherche français ou étrangers, des laboratoires publics ou privés. 


\title{
The use of pollen floras as a tool to estimate palaeoaltitude of mountains: the eastern Pyrenees in the Late Neogene, a case study
}

\author{
Jean-Pierre Suc ${ }^{1}$ and Séverine Fauquette ${ }^{2}$
}

1 Institut des Sciences de la Terre de Paris (UMR 7193 CNRS), Université Pierre et Marie Curie, 4 place Jussieu, case 117, 75252 Paris Cedex 05, France (jeanpierre.suc@gmail.com)

2 Institut des Sciences de l'Evolution de Montpellier, UMR CNRS 5554, Equipe Paléoenvironnements, case courrier 061, Université de Montpellier 2, Place Eugène Bataillon, 34095 Montpellier cedex 05, France (severine.fauquette@univ-montp2.fr)

Corresponding author: Jean-Pierre Suc (jeanpierre.suc@gmail.com)

\begin{abstract}
Northern Hemisphere vegetation is generally zoned as a consequence of latitudinal and altitudinal gradients. Temperature reconstruction from three successive pollen floral assemblages (of Tortonian, Messinian and Zanclean age) from the eastern Pyrenees has been used to estimate the altitudinal evolution of the uplifted Cerdanya Basin and its surrounding massifs. A new method has been developed for the uplifted basins, which completes that already applied to pollen floras from coastal marine deposits close to mountains. In contrast to previous hypotheses, it seems that the eastern Pyrenees occurred at a lower altitude in the Late Miocene before continuous uplift began $10 \mathrm{Ma}$ ago. The rate of this uplift ranged between 0.06 and $0.12 \mathrm{~mm} / \mathrm{yr}$.
\end{abstract}

Key-words: Pollen flora - Palaeotemperature - Mountain palaeoelevation - Uplifted basins.

\section{Highlights}

$>$ Pollen floras allow altitudes of eastern Pyrenees at 10, 7-6 and 5 Ma to be estimated. > A new method is applied to estimation of palaeoaltitudes of the Cerdanya uplifted basin. $>$ Topographic variation existed in the region before constant uplift since $10 \mathrm{Ma}$. 


\section{Introduction}

The estimate of palaeoaltitude of mountain belts and its change with time is essential for deciphering between movements of the earth surface caused by tectonics, mantle dynamics or climate. It is also essential for placing limits on erosion rates and terrigenous fluxes into sedimentary basins, the reconstruction of vegetation palaeomaps and the development of palaeoclimate models.

Different indirect approaches are used to estimate palaeoaltitudes with equivocal results: some of which provide evidence on denudation, such as thermochronometry (Gunnell, 2000) and geomorphology (Kooi and Beaumont, 1996; Babault et al., 2005). These depend in part on altitude; whilst others provide evidence on the physical conditions of water inclusions within newly crystallised minerals (Chamberlain and Poage, 2000) or those of carbonate precipitation (Mulch et al., 2004). These variables both depend on climate and relief. However, none of these methods considered alone can be used to indicate the true palaeoaltitude evolution of the earth surface.

Present-day vegetation changes according to latitude and altitude, with an almost constant variation with respect to decrease in temperature throughout the Northern Hemisphere, from the South to the North (Troll, 1966, 1973; Ozenda, 2002). As a consequence, plant remains may be used to estimate palaeoaltitudes. This was first applied in Northwestern America using plant macroremains frequently recorded at altitudes (Axelrod, 1965, 1968; Axelrod and Bailey, 1976; Meyer, 1992; Wolfe, 1995) using a relatively complex method in the absence of a calculated standard thermal gradient. The passage from thermophilous to boreal forests and the tundra is forced by decreasing mean annual air temperature (MAT). This regulates the thermal classification of plants $(\mathrm{Nix}, 1982)$ : equatorial then tropical forests, inhabited by megathermic plants (MAT $>24^{\circ} \mathrm{C}$ ), are gradually replaced by subtropical forests composed of mega-mesothermic plants $\left(20^{\circ} \mathrm{C}<\mathrm{MAT}<24^{\circ} \mathrm{C}\right)$, warm-temperate forests composed of mesothermic plants $\left(14^{\circ} \mathrm{C}<\mathrm{MAT}<20^{\circ} \mathrm{C}\right)$, mixed and coniferous forests composed of mesomicrothermic $\left(12^{\circ} \mathrm{C}<\mathrm{MAT}<14^{\circ} \mathrm{C}\right)$ then microthermic plants (MAT $<12^{\circ} \mathrm{C}$ ), and finally by the teundra (composed of microthermic herbs and some dwarf woody elements) that is stopped by snow and ice-dominated climates. This organisation of vegetation was used by Ozenda $(1975,1989,2002)$ who succeeded in establishing a standard relationship between the latitudinal and altitudinal thermal gradients. This author took average values for the Northern Hemisphere: $0.60^{\circ} \mathrm{C}$ per degree of latitude and $0.55^{\circ} \mathrm{C}$ per $100 \mathrm{~m}$ in altitude despite slight variability resulting from sunshine exposure. However, establishing such a latitudinalaltitudinal standard thermal gradient for the Northern Hemisphere left open new prospects for palaeoaltitude estimates using plant remains.

Pollen floras, which are generally more abundant than those of plant macrofossil assemblages, provide a broader overview of the vegetation both in latitude and altitude (Suc, 1989). Pollen data seem to provide an efficient tool, with a large potential geographical interest, since they may be extracted both from sedimentary foreland basins and uplifted intramountainous basins. An initial method has been developed for low altitude and coastal marine sediments located near massifs (Fauquette et al., 1999). This is based on quantification of past mean annual temperature (MAT), and using the past latitudinal and altitudinal thermal gradients and latitudinal versus altitudinal distribution of meso-microthermic (i.e. cooltemperate) and microthermic (i.e. boreal) trees. However, this approach only provides an estimate of the minimum palaeoaltitude of the massif because it concerns the lower limit of the highest forest belt. Imprecision is accentuated when an herbaceous belt covered the most elevated part of the massif (pollen analysis is not yet able to detect altitudinal meadows) and more amplified where the summit was continuously covered by ice. 
The Neogene latitudinal thermal gradient has been calculated for Europe and the Mediterranean region using pollen records: it is $0.48^{\circ} \mathrm{C}$ per degree of latitude for the Middle Miocene, $0.6^{\circ} \mathrm{C}$ per degree of latitude since the early Tortonian (Upper Miocene) (Fauquette et al., 2007). The 'modern-aspect' reconstructed gradient from pollen floras for the end of the Neogene is consistent with model simulations in particular for the Pliocene (Haywood et al., 2000a and b; Jost et al., 2009).

In this paper, the authors present a new method based on pollen records from sediments uplifted following deposition. The estimated altitude of massifs is, in the case of Late Neogene of the eastern Pyrenees, compared to that obtained using the method for low altitude and coastal sediments (Fauquette et al., 1999).

\section{The eastern Pyrenees and the study basins}

The formation of the Pyrenees follows a complex tectonic history that began in the Palaeozoic, in relation to compressional deformation and metamorphism in the Pyrenean Axial Range (Arthaud and Matte, 1975). The Hercynian chain is then largely eroded, until the Cretaceous. At about $90 \mathrm{Ma}$, the Iberian Plate moved along a left-lateral strike-slip fault relative to the European Plate as a result of deep-seated modification of the Atlantic Ocean (Olivet, 1996). This plate boundary is represented by the North Pyrenean Fault (Fig. 1B). The Pyrenean orogen grew from the Late Cretaceous to the Early Miocene as a result of the collision between the Iberian and the European plates (e.g. Munoz, 1992). The initiation of the collisional stage at ca. $80 \mathrm{Ma}$ was accompanied by the tectonic inversion of Early Cretaceous extensional basins. Following the slowing of the European/Iberian plate convergence at $\sim 65 \mathrm{Ma}$ (Roest and Srivastava, 1991), thrust activity resumed at $50 \mathrm{Ma}$. At 35$30 \mathrm{Ma}$, the exhumation rates accelerated to $2-4 \mathrm{~km} / \mathrm{Ma}$, in response to increasing thickening of the Iberian crust through underplating in the central Pyrenees (Fitzgerald et al., 1999) eventually enhanced by the Eo-Oligocene global cooling (Huyghe et al., 2009). Between the Late Cretaceous and the Eocene, the Iberian Plate followed a convergent motion relative to the European Plate, the rotation pole being located southwest of Iberia and consequently the compressional motion increased eastwards (Olivet, 1996). Later, compression decreased (Gorini et al., 1993). After the collision or during the last phase of plate convergence, the eastern Pyrenees (Fig. 1) were affected by a period of crustal thinning related to the welldefined Oligocene - Early Miocene rifting seen in the Gulf of Lions (Mauffret et al., 2001) that preceded the formation of the Western Mediterranean Sea (Réhault et al., 1984; Gorini et al., 1993). According to Mauffret et al. (2001), a second extensional event took place between the Late Miocene and the Early Pliocene. These authors suggest that prominent tectonic activity occurred during the Late Miocene, with most of the faults formed during this interval being sealed by the Messinian Erosional Surface. However, these authors consider that some extensional activity apparently persisted into the Early Pliocene but not later. Other authors (e.g. Briais et al., 1990) assume that extension in the eastern Pyrenees continued during the Quaternary including the present day.

The eastern Pyrenees include two sedimentary basins infilled by Neogene sediments containing abundant pollen (Figs. 1B, 1C): (1) the uplifted Cerdanya Basin which today reaches an altitude of 1000 to $1200 \mathrm{~m}$, bordered by high peaks up to $c a$. $2900 \mathrm{~m}$ a.s.l. This basin is characterised by two successive pollen floral assemblages, at Sanavastre and Sampsor (Bessedik, 1985; Suc, 1989) and Can Vilella (Agusti et al., 2006; Fauquette et al., 2006), respectively of Tortonian and Messinian age (i.e. Upper Miocene) (Fig. 2); (2) the Roussillon coastal Zanclean Basin at the foot of the Canigou Mount, reaching an altitude of $2784 \mathrm{~m}$ (Fig. 2). 
Uplift of the Cerdanya Basin was proposed by Mauffret et al. (2001) as having occurred mainly during the Middle to Late Miocene (between 10 and $5 \mathrm{Ma}$ ). During the 1990s, an intense debate arose concerning the tectonic activity in the eastern Pyrenees that took the form of destructive earthquakes in the area (for instance at Olot in 1427-1428; Olivera et al., 2008). For some authors, the associated normal faults indicate important tectonic activity during the Quaternary (Briais et al., 1990).

Uplift of the Canigou Mount (Figs. 1B, 1C) occurred during the Late Miocene - Early Pliocene, as a result of a flexural isostatic rebound caused by crustal thinning. Based on the study of apatite fission tracks, Maurel et al. (2002) proposed that the onset of the exhumation of the Canigou Massif took place at around 27-26 Ma (Oligocene - Miocene). According to these authors, a second and last uplift pulse of the Canigou Mount occurred during the Messinian Salinity Crisis in the latest Miocene.

\subsection{The Cerdanya Basin}

The Cerdanya Basin is a SW-NE orientated half-graben (Figs. 1B, 1C) impacted by two tectonic phases (Pous et al., 1986; Cabrera et al., 1988; Roca, 1996): (1) during the MiddleLate Miocene, an intense fracturing of the eastern Pyrenees basement occurred, resulting in the dextral slip of the deep Têt Fault which formed the Cerdanya Basin; (2) in the latest Miocene (Messinian), the sedimentation terminated under a generally extensional situation. Neogene sediments, mostly consisting of fluvial sands and conglomerates, are 400 to $1000 \mathrm{~m}$ thick as a consequence of an intense subsidence (Agustí and Roca, 1987; Roca, 1996). These sediments consist of two units separated by an unconformity the lower unit being folded during an intervening phase (Cabrera et al., 1988). However, they contain diatomite, clay and lignite layers rich in mammal, ostracod and plant remains (including pollen).

Fossil mammals from the Sanavastre and Prats-Sampsor localities (Cerdanya Lower Unit) belong to the Vallesian continental period (mammal zones MN 9-10). This is based particularly on the presence of Hipparion primigenium catalaunicum (Agustí and Roca, 1987), i.e. to the $c a$. 11-9 Ma interval (equivalent for a part to the Tortonian Stage) (Fig. 2; Agustí et al., 2001).

The Can Vilella section exposes part of the Upper Unit. It contains small mammal teeth and bones which indicate that this Turolian fauna is of early Messinian age, based on palaeomagnetic measurements. It can be correlated to date from between Chrons C3An.2n or C3An.1n for the topmost section (Fig. 2; Agustí et al., 2006). Whilst these authors argued in favour of a Chron C3An.1n date some doubt still remains. A revised biochronology of the Iberoccitanian mammal faunas supports the youngest hypothesis (Gómez Cano et al., 2011). Nevertheless, the present authors consider this pollen flora occurred between $c a$. 7 and $6 \mathrm{Ma}$, with the opportunity to test the two possible ages, close to 6.5 or $6.1 \mathrm{Ma}$, respectively.

Agustí et al. (2006) proposed the elevation of Cerdanya reached at least $500 \mathrm{~m}$ during the Tortonian and over $1000 \mathrm{~m}$ in the late Messinian, considering that the difference in altitude between the Cerdanya Basin and the bounding high massifs to the North and South was already of the same order as that today, i.e. up to $1900 \mathrm{~m}$ (Fig. 1C). However, this assumption differs from that of Briais et al. (1990), Coney et al. (1996) and Fitzgerald et al. (1999) who consider that the contrasting topography of the southern flank of the Pyrenees arose from erosion during the Messinian sea-level fall, rather than uplift.

\subsection{The Roussillon Basin}

The Roussillon Basin is a Neogene graben that was initially infilled by $c a .2000 \mathrm{~m}$ of Miocene deposits, then deeply eroded during the desiccation phase of the Messinian Salinity Crisis (Clauzon, 1990). Zanclean coastal marine sediments, deposited within three deep coalescing rias, resulting from the Messinian fluvial canyons that were filled by sea when the 
Mediterranean Basin was reflooded (Clauzon et al., 1990; Bache et al., 2011). The Roussillon Basin is bordered to the west and south by the Pyrenees (the Aspres and Albères massifs, respectively), the Canigou Mount, composed of Hercynian rocks, reaching $2784 \mathrm{~m}$ only 49 $\mathrm{km}$ from the shoreline (Figs. 1B, 1C).

The basin contains abundant well-dated Zanclean pollen localities (Suc, 1976; Cravatte et al., 1984; Suc, 1989; Suc et al., 1992). Two localities, Le Boulou and Vivès, very close to the Canigou Mount (at 31 and $26.5 \mathrm{~km}$, respectively), have provided rich pollen floral assemblages which are good candidates for estimating the altitude of the Canigou Mount in the early Zanclean (Fig. 2). Unfortunately, there is no Miocene pollen locality in the basin to provide an older pollen assemblage for comparison.

The Le Boulou section exposes clays ( $79 \mathrm{~m}$ thick) representing the prograding bottomset beds of a Zanclean Gilbert-type fan delta (Clauzon, 1990). This accumulation was dated using planktonic foraminifers from the Elne 1 and Canet 1 boreholes (Cravatte et al., 1984), and include the C3n.4n normal Chron (Fig. 2; Clauzon et al., 1990). The Vivès section includes thin lignite beds immediately overlying the prograding foreset beds and forming the marinecontinental transition of the same Gilbert-type fan delta in its proximal part (Clauzon, 1990). These beds have yielded a rodent faunal assemblage (locality Vivès 2) which is of earliest Zanclean age (Fig. 2; Aguilar and Michaux, 1987; Clauzon et al., 1990).

\section{Late Neogene vegetation in the eastern Pyrenees}

\subsection{Early Tortonian vegetation in Cerdanya}

On the basis of the Sanavastre $\left(42^{\circ} 23^{\prime} \mathrm{N}-1^{\circ} 51^{\prime} \mathrm{E}\right.$; Figs. 1B, 1C) and Sampsor $\left(42^{\circ} 22^{\prime} 50^{\prime} \mathrm{N}-\right.$ $1^{\circ} 49^{\prime} 50^{\prime}$ E; Figs. 1B, 1C) plant macro-remain and pollen localities (Figs. 1B, 1C, 3A, 3C), the early Tortonian Cerdanya lake was bordered by swamps that supported a luxuriant riparian forest (Martín-Closas, 1995). This is indicated by a diverse macroflora (Glyptostrobus europaeus, Zelkova ungeri, Ulmus braunii, Taxodium distichum miocenicum, several Alnus, Salix and Populus species, Carya bilinica, Pterocarya denticulata, Myrica salicina and M. vindobonensis, Parrotia pristina and P. gracilis, etc.: Menéndez Amor, 1955) and microflora (Alnus, Carya, Liquidambar, Myrica, Nyssa, Parrotia persica, Pterocarya, Populus, Salix, Taxodiaceae including Taxodium-type, Ulmus, Zelkova: Bessedik, 1985). Water plants colonised the most humid areas and/or marshes (macroflora: Typha latissima, Trapa ceretana, Poaceae p.p., Cyperaceae; Menéndez Amor, 1955; microflora: Haloragis, Nympheaceae, Oenotheraceae, Potamogeton, Restionaceae, Sparganium, Typha, Poaceae p.p., Cyperaceae; Bessedik, 1985).

As Menéndez Amor (1955) points out that the Cerdanya flora probably grew at a significantly lower altitude than that of the area today based on the occurrence of the abundant evergreen mega-mesothermic (i.e. subtropical) plants: Taxodiaceae (Taxodium, Glyptostrobus), Lauraceae (Laurus princeps, Cinnamomum lanceolatum, Sassafras ferretianum, Persea braunii, P. spinosa), Araucariaceae (Doliostrobus rerollei), Moraceae (Ficus tiliaefolia, F. pulcherrima), Proteaceae (Embothrium microspermum, Dryandroides aff. banksioefolia), D. lignitum, Banksia deikeana, B. helvetica, Conospermum macrophyllum), Fabaceae Caesalpinoideae (Caesalpinia cf. lepida, C . townshendi, $C$. micromera, Cassia paleogea, C. ambigua, C. lignitum, C. berenices), Sapindaceae (Sapindus dubius), Celastraceae (Celastrus crassifolius), Sapotaceae (Sapotacites minor, S. parvifolius), etc. This aspect is supported by pollen flora (Bessedik, 1985) with Cassia (Fabaceae Caesalpinoideae), Celastraceae, Distylium (Hamamelidaceae), Engelhardia and Platycarya (Juglandaceae), Nyssa cf. sinensis (Nyssaceae), Sapotaceae, and Taxodiaceae (Fig. 3B, 3D). 
Development of vegetation belts above those mentioned is demonstrated by Menéndez Amor (1955) by successively (1) deciduous mesothermic (i.e. warm-temperate) plants (Acer, Juglans, many Quercus species, Carpinus, Ostrya, Betula, Tilia, Platanus, Castanea, Buxus sempervirens, etc.), (2) deciduous meso-microthermic (i.e. cool-temperate) plants (Fagus pliocenica var. ceretana, F. pristina, F. cf. castanaefolia), and (3) evergreen conifers (Pinus, Abies saportana). Such an altitudinal organization is also clear when considering the pollen flora (Bessedik, 1985; see the Method section for further explanation): (1) a deciduous mesothermic assemblage (Acer, Buxus sempervirens, Carpinus, Celtis, Juglans, Ostrya, Platanus, Quercus), (2) a mixed meso-microthermic assemblage (Fagus and Cathaya mainly, Tsuga), and (3) a coniferous microthermic assemblage (Pinus p.p., Abies) (Fig. 3B, 3D).

Palaeoclimatic parameters have been determined for the lowermost vegetation belt of Cerdanya using the 'Climatic Amplitude' transfer function for pollen records (Fauquette et al., 1998): the mean annual temperature (MAT) is between $15.5^{\circ} \mathrm{C}$ and $19.8^{\circ} \mathrm{C}$ with a 'Most Likely Value' (MLV) of $17.4^{\circ} \mathrm{C}$ (Table 1), the annual precipitation between 1100 and 1600 mm with a MLV at $1300 \mathrm{~mm}$ (Fauquette et al., 2007; Jiménez-Moreno et al., 2010).

To summarise, these data indicate that the Cerdanya Basin was significantly lower in altitude during the early Tortonian than today because it supported a rich mega-mesothermic flora. Indeed, the present-day flora mostly comprises mesothermic and meso-microthermic elements (Quercus pubescens, Acer, Corylus, Betula, etc.; Gaussen, 1972; Gaussen et al., 1972). In addition, the surrounding massifs were already relatively high according to the critical elevated frequency of meso-microthermic and microthermic elements, especially in the pollen record. A slight cooling seems to have characterised the Sampsor pollen flora by comparison with that of Sanavastre, resulting in a larger representation of Abies (Fig. 3D) probably caused by some descent of the most elevated forest belt.

\subsection{Early Messinian vegetation in Cerdanya}

The early Messinian vegetation of Cerdanya is only documented by pollen data from the

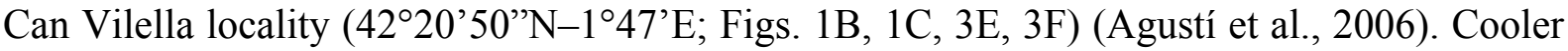
conditions than during the Tortonian characterise the Can Vilella flora since it contains only a few mega-mesothermic elements (Cyrillaceae-Clethraceae, Engelhardia, Leea, Nyssa, Sapotaceae and Taxodiaceae) with a predominance of Taxodiaceae and, at a lesser extent, Engelhardia (Fig. 3G). This could result from tectonic uplift of the area because no major cooling occurred within the time interval 10-6 Ma (Zachos et al., 2001; Westerhold et al., 2005). Early Messinian riparian forests were dominated by Alnus, Carya, Pterocarya, Salix, Ulmus, Zelkova, and above all Taxodiaceae, all of which maintained swampy and marshy (according to the high frequency of Cyperaceae and Poaceae p.p.) environments. A similar altitudinal organisation of the vegetation persisted (see the Method section for further explanation) with a more pronounced opening of forests according to the large frequency of herbs (Fig. 3G). Nearby high summits existed based on the occurrence of Abies and Picea.

As previously, palaeoclimatic parameters have been calculated: MAT is between $15.5^{\circ} \mathrm{C}$ and $19.8^{\circ} \mathrm{C}$ with $\mathrm{MLV}$ at $17^{\circ} \mathrm{C}$ (Table 1), the annual precipitation lay between 1070 and $1300 \mathrm{~mm}$ with MLV at $1100 \mathrm{~mm}$ (Fauquette et al., 2006).

\subsection{Early Zanclean vegetation in the Roussillon Basin}

Two pollen localities, Le Boulou (from 42 $31^{\prime} 24^{\prime} \mathrm{N}-2^{\circ} 50^{\prime} 38^{\prime \prime} \mathrm{E}$ to $42^{\circ} 32^{\prime} 29^{\prime \prime}-2^{\circ} 52^{\prime} \mathrm{E}$; Fig. $1 \mathrm{~B})$ and Vivès $\left(42^{\circ} 31^{\prime} 36^{\prime \prime} \mathrm{N}-2^{\circ} 47^{\prime} \mathrm{E}\right.$; Fig. 1B), yield evidence for the vegetation of the Roussillon Basin and the eastern slope of the Canigou Mount during the early Zanclean (Figs. 4 and 5). These localities are very close to the Canigou Mount as can be seen in Figure 5C. Taxodiaceae swamps (with Nyssa) and marshes (with Cyperaceae, Myrica, CyrillaceaeClethraceae, Poaceae and water plants such as Typha, Potamogeton, Euphorbia cf. palustris) 
occupied the coastal sites. The lowlands were inhabited by a subtropical forest composed of evergreen and deciduous trees, such as Sapotaceae, Hamamelidaceae (Hamamelis, Distylium), Celastraceae, Menispermaceae, Taxodiaceae, Arecaceae, Juglandaceae (Engelhardia) and Fagaceae (Quercus). Rivers were bordered by a riparian forest with Alnus, Salix, Populus, Pterocarya, Liquidambar, Ulmus, Zelkova, Parrotia persica and Platanus, etc. Evergreen sclerophylous elements lived in drier places (Mediterranean xerophytes: Olea, Phillyrea, Pistacia; Microtropis fallax and Pinus p.p.). The lower slopes of the Canigou Mount supported deciduous forest (Quercus, Carya, Carpinus, Acer, Tilia, Betula, etc.), successively replaced at higher altitudes by a mixed forest (with Fagus, Cedrus, Cathaya, Sciadopitys, Tsuga and Pinus p.p.) and a coniferous forest (Abies, Picea, Pinus p.p.) (cf. Method for further explanation). Accordingly, the altitude of Canigou Mount was already high at that time.

Following the same method as for the Late Miocene, palaeoclimatic parameters have been determined: MAT is between $14.6^{\circ} \mathrm{C}$ and $17.7^{\circ} \mathrm{C}$ with $\mathrm{MLV}$ at $16.5^{\circ} \mathrm{C}$, the annual precipitation between 1180 and $1270 \mathrm{~mm}$ with a MLV at $1200 \mathrm{~mm}$ (Fauquette et al., 2007).

\section{Method for estimating palaeoaltitude of an uplifted basin}

Tectonic motion of uplifted basins requires quantification over long periods, if possible supported by multiple approaches. Axelrod (1997) devised a method based on the estimated difference in temperature between a palaeoflora from an uplifted locality and a similar modern flora living in lowlands. The present authors have developed a different method, based on the same concept but using almost coeval Neogene pollen floras (i.e. located in the same chronological range as the pollen flora studied: see Figure 2 and text below), which benefits from several advantages:

- lowland pollen localities selected for comparison are relatively frequent since they are coastal marine sediments which are often accurately dated,

- thermal latitudinal and altitudinal gradients established by Ozenda (1989) allow a standardised application,

- quantification of the latitudinal thermal gradient for the Neogene of Europe (Fauquette et al., 2007) allows the use of the modern values for the period since the earliest Tortonian.

The method perfected for this purpose is as follows (Fig. 6):

- as mentioned above, the MAT is calculated for the uplifted pollen locality at the time of deposition, this is the value $t_{1}$;

- MAT is also calculated for a contemporaneous stable pollen locality in the lowlands, this is the value $t_{2}$;

- the present-day difference in latitude (Dl) between the two localities is measured, possibly replaced by the palaeodifference obtained from palinspastic reconstructions for the studied time);

- MAT $t_{2}$ is translated into $t_{3}$ using the difference in latitude (or palaeolatitude) between the two localities with respect to the latitudinal thermal gradient (or palaeogradient) (Lgr expressed in ${ }^{\circ} \mathrm{C}$ per degree of latitude) using the equation: $t_{3}=t_{2}+\left(D 1 x\right.$ Lgr); MLV of $t_{3}$ is considered as MAT of the pollen locality if it was not uplifted;

- palaeoelevation (Pe expressed in hundred metres) of the pollen locality at the time of sediment deposition is obtained using the difference in MLV of $t_{3}$ and $t_{1}$ and applying the altitudinal thermic gradient (or palaeogradient) (Agr expressed in ${ }^{\circ} \mathrm{C}$ per hundred metres) according to the equation: $\mathrm{Pe}=(\mathrm{t} 3-\mathrm{t} 1) /$ Agr.

This method has been tested to estimate the palaeoaltitude of the Cerdanya Basin during the early Tortonian (11-9 Ma) and early Messinian (7-6 Ma) times. The authors used the same 
modern thermal gradient as that of Fauquette et al. (2007) and established that the shift from a latitudinal thermal gradient at $0.48^{\circ} \mathrm{C}$ per degree of latitude to the modern one $\left(0.6^{\circ} \mathrm{C}\right.$ per degree of latitude) was already achieved at $11 \mathrm{Ma}$.

The palaeoaltitude estimates were calculated using the MLVs of MAT obtained from pollen data. The MLVs are certainly less representative of the climate than the entire reconstructed climatic amplitude (as plants may sometimes support large climatic ranges), however they provide a good idea of the optimum climate where they best develop. Moreover MLVs have been statistically tested on modern pollen data and, as a consequence, they are considered to give reliable results (Fauquette et al., 1998).

A validation of the method may be achieved using a modern pollen flora sampled at Col de Jau ( $42^{\circ} 41^{\prime} \mathrm{N}-2^{\circ} 15^{\prime} \mathrm{E}$; cf.: Supplementary data 1 and 2 ) using a method developed by Cour (1974). This consists of whipping up dust (including pollen grains) and collecting it on filters, using a car travelling along several two-way journeys on a pathway ( $1 \mathrm{~km}$ long at constant altitudinal level). Simultaneously, a plant inventory of the area is obtained in order to determine which pollen grains are of local origin and which are not. The climatic reconstruction from the Col de Jau pollen flora indicates an MAT between 3 and $12^{\circ} \mathrm{C}$ with MLV around $7.5^{\circ} \mathrm{C}$. This value is found today for example at around $58^{\circ} \mathrm{N}$ in Norway, i.e. $15^{\circ}$ further north than the Col de Jau locality. Using the relation established by Ozenda (1975, 1989), this difference in latitude indicates an estimated altitude of the sampled site of $\sim 1650$ metres a.s.l. Actually, Col de Jau occurs today at $1506 \mathrm{~m}$ a.s.l. In the same way, the climatic reconstruction determined from a modern pollen flora sampled at Canet - Saint-Nazaire, at sea level (42 $40^{\prime} \mathrm{N}-3^{\circ} 00^{\prime} \mathrm{E}$; cf.: Supplementary data 1 and 2$)$ indicates MAT between 9.5 and $24.7^{\circ} \mathrm{C}$ with an MLV around $16.7^{\circ} \mathrm{C}$. Using the same approach as that used for the fossil pollen data, comparing the two modern sites which occur at the same latitude, a difference of MAT of $9.2^{\circ} \mathrm{C}$ indicates a reconstructed altitude of about $1670 \mathrm{~m}$ for Col de Jau. These results indicate that, although the reconstructed climatic interval is large, the MLV gives a reliable estimate for the site's altitude at the time of deposition.

For a large part, the reconstructed altitudinal vegetation depends on the assumption that the Neogene plants occurred in the same altitudinal vegetation belts (Fig. 7) as those today, as assumed above. This consideration of two altitudinal vegetation belts (a Cathaya - Tsuga Cedrus belt succeeded by an Abies - Picea belt) results from interpretation of a large set of data established over a long time period (Suc, 1989; Suc et al., 1999):

- pollen floras (coastal marine and lowland lacustrine localities) from the four bestdocumented Neogene stages (Burdigalian, Langhian, Messinian, Zanclean) show enrichment in Cathaya and Tsuga (and often Cedrus) near old (or lower) massifs. They also show an enrichment in Abies and Picea near recent (higher) massifs (Bessedik, 1985; Suc, 1989; Suc et al., 1995b and c, 1999; Popescu, 2001, 2006; Jiménez-Moreno, 2005; Fauquette et al., 2006; Popescu et al., 2006, 2010; Jiménez-Moreno et al., 2007a; Jiménez-Moreno and Suc, 2007; Jiménez-Moreno et al., 2010);

- concerning the Alps, these pollen floral assemblages show enrichment in Cathaya (Aquitanian-Burdigalian) prior to that in Abies and Picea (Langhian to Zanclean). This is interpreted as reflecting increasing elevation of the chain (Suc et al., 1992; JiménezMoreno et al., 2005, 2008);

- the spatial distribution of plants, with respect to their latitudinal replacement at a given moment, is consistent with the proposed altitudinal arrangement (Fauquette et al., 2007);

- palaeovegetation maps obtained from interpolated pollen data (Favre, 2007) or from palaeoclimate modelling (François et al., 2011), also support this vegetational organisation.

These conclusions confirm the present vegetation of China as the best model for the organisation of Neogene vegetation in southern Europe (Fig. 7). 
At first sight, the method applied herein could possibly appear to be biased by variations in temperature relative to astronomical cycles, for example if two pollen floras from the same chronological interval indicating different temperature are compared. During the warm Miocene and Pliocene interval, variability in MAT did not usually exceed $2^{\circ} \mathrm{C}$ in the Mediterranean region (Fauquette and Bertini, 2003; Jiménez-Moreno et al., 2005, 2007b; Fauquette et al., 2006), whereas it was significantly more important during the Quaternary $\left(>6^{\circ} \mathrm{C}\right.$; Fauquette and Bertini, 2003; Klotz et al., 2006). Accordingly, such a variability of $\pm 1^{\circ} \mathrm{C}$ for the Neogene could be neglected because the method is designed to provide a rough guide to palaeoaltitude rather than its precise value. In addition, when several varying pollen spectra are obtained from a locality, they can be grouped when an MAT representative of the whole time-span of the sediments is determined. This is the case for the Sanavastre, Sampsor and Can Vilella sequences and their comparative pollen floras from Alboran A1, Montredon, Douiet 1, Capodarso, respectively. In this way, the potential variability in temperature has been integrated into the calculations.

\section{Early Tortonian and early Messinian palaeoaltitude of the Cerdanya Basin}

\subsection{During the early Tortonian (11-9 Ma)}

The pollen assemblage of marine sediments at 1073-1129 $\mathrm{m}$ depth from the offshore Alborán A1 borehole (Alboran Sea: 36³8'N-4¹3'23'E; Fig. 1A) is the closest site contemporaneous with the Sanavastre-Sampsor pollen floras. The well-dated (by planktonic foraminifers) Tortonian marine sediments from the Alborán A1 borehole (Fig. 2) provided a pollen assemblage dominated by herbs representative of the nearby coastal lowlands at the time of closure of the Betic Corridor. They also occurred before the significant elevation of the Betic Ranges (Krijgsman, 2002) documented by low abundance of Cathaya (JiménezMoreno, 2005; Fauquette et al., 2007; Jiménez-Moreno et al., 2010). The MAT range for this pollen flora $\left(\mathrm{t}_{2}\right)$ is $17-25^{\circ} \mathrm{C}$ with an MLV of $20.3^{\circ} \mathrm{C}$ (Jiménez-Moreno et al., 2010). Today, the difference in latitude between these two localities is $5^{\circ} 45^{\prime}$. However it can be reduced to $4^{\circ}$ (Dl) if palinspastic reconstructions for the Serravallian-Tortonian times are reconsidered (Meulenkamp and Sissingh, 2003; Paramanova et al., 2004). In this case the translated MLV $\mathrm{t}_{3}$ (using Lgr at $0.6^{\circ} \mathrm{C}$ per degree of latitude; Fauquette et al., 2007) equals $17.9^{\circ} \mathrm{C}$. Considering an Agr value at $0.55^{\circ} \mathrm{C}$ per $100 \mathrm{~m}$ (Fauquette et al., 2007), this gives a palaeoelevation (Pe) of $c a .100 \mathrm{~m}$ based on the MLV (Table 1) bearing in mind that the climatic ranges are large.

Similarly, the authors compared the Sanavastre-Sampsor pollen floras with that from the early Tortonian-age levels of the Montredon locality in southern France (43 ${ }^{\circ} 11^{\prime} \mathrm{N}-2^{\circ} 55^{\prime} \mathrm{E}$; Fig. 1A). At Montredon, lacustrine sediments (dated by mammal zonation: Aguilar et al., 2004; Fig. 2) provided a pollen assemblage derived from the North Pyrenean lowlands. It includes an indication of moderate relief by the presence of Cathaya pollen (Bessedik, 1985). The Montredon MAT range is $15-22^{\circ} \mathrm{C}$ with a MLV at $17^{\circ} \mathrm{C}$. Today, the difference in latitude between the two localities is $48^{\prime}$ (i.e. $0.80^{\circ}$ ), but can be reduced to $0.74^{\circ}$ based on palinspastic reconstructions (Meulenkamp and Sissingh, 2003; Paramanova et al., 2004). Here the MLV t 3 should equal $17.4^{\circ} \mathrm{C}$ if Sanavastre-Sampsor was at sea level (Table 1). This suggests that the Cerdanya Basin occurred near the seashore at a very low palaeoaltitude at that time.

Such a low palaeoaltitude can be seen within the range of significance of the 'Climatic Amplitude' transfer function which concerns 'low/middle - low altitude vegetation', i.e. approximately the lowermost $200 \mathrm{~m}$ (Fauquette et al., 1998). Therefore, the authors consider a maximum elevation of $200 \mathrm{~m}$ a.s.l. for the Cerdanya Basin during the early Tortonian interval 
(Fig. 8), an option consistent with the palaeogeographic map published by Paramanova et al. (2004).

\subsection{At the early Messinian (7-6 Ma)}

Two pollen floras have been used for this estimation:

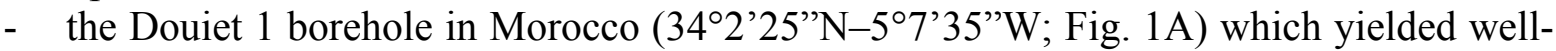
dated (by planktonic foraminifers) marine sediments (Fig. 2); its pollen assemblage, dominated by xeric herbs, originated from the nearby lowlands bordering the northern shoreline of the Rifan Corridor. here deciduous Quercus is the sole indicator of some local relief (Bachiri et al., 2008);

- the Capodarso exposure in Sicily $\left(37^{\circ} 33^{\prime} \mathrm{N}-14^{\circ} 9^{\prime} \mathrm{E}\right.$; Fig. 1A), the uppermost part of which exposes marine coastal sediments including Chron C3An.1n (Fig. 2; Suc et al., 1995a). The contained open xeric pollen assemblage derived from nearby lowlands at the foot of the Nebrodi-Madonie Mounts, the low elevation of which is indicated by the occurrence of deciduous Quercus and rare Cathaya pollen (Suc et al., 1995a).

The MAT values have been calculated for this sequence using the 'Climatic Amplitude' transfer function, and gave the following ranges (Fauquette et al., 2006):

- Douiet 1: 21.6-24.7 ${ }^{\circ} \mathrm{C}, \mathrm{MLV}$ at $23.6^{\circ} \mathrm{C}$;

- Capodarso: $15.6-24.7^{\circ} \mathrm{C}, \mathrm{MLV}$ at $22.5^{\circ} \mathrm{C}$.

Applying the same calculation as previously for the MLV values, after taking into account difference in palaeolatitude, indicated by Khondkarian et al. (2004) (Table 1), an elevation of $250 \mathrm{~m}$ with respect to the Douiet 1 palaeotemperature and $600 \mathrm{~m}$ with respect to the Capodarso palaeotemperature was obtained (Table 1).

The present palaeoaltitude estimates for the Cerdanya Basin, though they are not sufficiently precise, offer an indication of a trend in its uplift progression since $10 \mathrm{Ma}$ (Fig. 7). At that time, a maximum palaeoaltitude is suggested to be $200 \mathrm{~m}$ considering the imprecision arising from the 'Climatic Amplitude' transfer function (see above). From this, two options can be suggested (Fig. 8):

- option A, with an elevation of $c a .250 \mathrm{~m}$ at $6.5 \mathrm{Ma}$ (just before the end of Chron C3An.2n); this option suggests an accelerated uplift rate since $6.5 \mathrm{Ma}$;

- option B, with an elevation of $c a .600 \mathrm{~m}$ at $6.1 \mathrm{Ma}$ (just before the end of Chron C3An.1n); this option suggests an almost constant uplift rate from $10 \mathrm{Ma}$ to the present.

In either case, these options differ significantly from option $\mathrm{C}$ proposed by Agustí et al. (2006), which suggested a marked decrease in the uplift rate since $6 \mathrm{Ma}$ (Fig. 8).

\section{Palaeoaltitude of the Canigou Mount in the early Zanclean}

The early Zanclean pollen floras of the south Roussillon Basin (Figs. 4 and 5), described above, are rich in Cathaya, Cedrus and Tsuga, Abies and Picea. These results imply that a complete altitudinal forest succession occurred on the Canigou Massif when subtropical climatic conditions dominated on the coastal plain. This observation allows the application of the method developed by Fauquette et al. (1999) for estimating a minimum palaeoaltitude of the Canigou Mount. This method takes into account pollen assemblages accumulated near the coast that provides a regional view of the vegetation from the coastal beaches to the uppermost altitudinal belts.

Ozenda (1989) established that a shift of $1 \mathrm{~km}$ to the north is equivalent, from a bioclimatic point of view, to a shift of 1 metre in altitude. Therefore, today, vegetation belts shift by a mean value of 110 metres in altitude per degree in latitude. Applying this relationship, the 
vegetation distribution to the climatic estimates, it is possible to reconstruct the altitude of the Canigou Mount at time in the earliest Pliocene:

- at that time, the MAT at Le Boulou, situated at about $42.5^{\circ} \mathrm{N}$ latitude, was about $16.5^{\circ} \mathrm{C}$ on the coast (range comprised between 14.6 and $17.7^{\circ} \mathrm{C}$ ) (Fauquette et al., 2007). Today, such a temperature occurs south of Valencia in Spain, at about $38.5^{\circ} \mathrm{N}$ latitude on the seashore, i.e. about $4^{\circ}$ lower in latitude than Le Boulou (or between 1.5 and $6^{\circ}$ lower in latitude if the range of reconstructed MAT is considered);

- using the relationship established by Ozenda $(1975,1989)$, a shift of $4^{\circ}$ in latitude corresponds to a mean shift of about $440 \mathrm{~m}$ in altitude. Thus, in the earliest Pliocene, vegetation belts should be shifted about $440 \mathrm{~m}$ higher (or 165 to $660 \mathrm{~m}$ based on the MAT interval mentioned above);

- today, Abies may be established between ca. 900 (the lowest altitude of occurrence of individual Abies trees) and $2000 \mathrm{~m}$ high in the Canigou Massif. However, the lower altitudinal limit of fir forests in this massif can be estimated at an altitude $c a .1700 \mathrm{~m}$ (Fig. 7; Gaussen et al., 1972; Gruber, 1980). Taking into account the shift of $440 \mathrm{~m}$ in vegetation belts between modern day and the earliest Pliocene, fir occurred since about $2140 \mathrm{~m}$ or 1865 to $2360 \mathrm{~m}$, based on the climatic interval (Fig. 9). These values are an estimate of palaeoaltitude of the lower limit of the Abies belt. Therefore, they indicate only a minimum altitude for the Canigou Mount at the beginning of the Pliocene. It should be at least $1865 \mathrm{~m}$ high above the sea level and more probably higher than 2140 m (Fig. 8).

\section{The altitudinal difference between Cerdanya and the surrounding massifs}

It is also possible to attempt to estimate the altitude of massifs surrounding the Cerdanya Basin in early Tortonian and early Messinian times. For this purpose, the MLV of MAT indicated by pollen assemblages of Sanavastre-Sampsor and Can Vilella are used here (Table 1).

Applying a value of $0.55^{\circ} \mathrm{C}$ per $100 \mathrm{~m}$ for the altitudinal thermal gradient (Agr) to the early Tortonian, it is possible to use the translated MLV of MAT value at sea level for the Sanavastre-Sampsor pollen floras ( $t_{3}$ calculated from Montredon and Alborán localities in Table 1). In this case they would fall between 17.4 and $17.9^{\circ} \mathrm{C}$. The Sanavastre-Sampsor pollen floras indicate a vegetation belting capped by the Abies forest. The authors determine the latitudes where such values of MAT are recorded today. These latitudes are reported on the altitude versus latitude distribution of the Abies belt that allows to determine its basal altitude and hence a minimum altitude of the nearby Puigmal and Carlit massifs (today 2910 and $2921 \mathrm{~m}$, respectively; Fig. 1C). At present, these temperatures are recorded further to the south, at around $37^{\circ}$ and $36.4^{\circ} \mathrm{N}$, respectively. Adopting the relationship established by Ozenda $(1975,1989), 1^{\circ}$ of latitude corresponds to $110 \mathrm{~m}$ in altitude, and the present-day lower altitudinal limit of Abies in these massifs (around 1700 m: Fig. 7; Gaussen et al., 1972; Gruber, 1980), the Puigmal and Carlit massifs should be at least $2300 \mathrm{~m}$ high at 11-9 Ma (Fig. 8).

As the Can Vilella pollen flora demonstrates the Abies and Picea pollen evidences, the same calculation made for the early Tortonian can be performed for estimating palaeoaltitude of the Puigmal and Carlit massifs during the early Messinian. Here the two optional translated values of the MLV of MAT of the Can Vilella pollen flora at sea level of $18.4^{\circ} \mathrm{C}$ and $20.4^{\circ} \mathrm{C}$ ( $\mathrm{t}_{3}$ calculated from Douiet 1 and Capodarso localities in Table 1), correspond to $250 \mathrm{~m}$ or 600 $\mathrm{m}$ (options A and B in Figure 8, respectively) of palaeoaltitude for the Cerdanya Basin. This results in two options for the minimum altitude of the nearby massifs. Today these 
temperatures are recorded further to the south, respectively around $37.5^{\circ} \mathrm{N}$ and around $35^{\circ} \mathrm{N}$. Therefore, the Puigmal and Carlit massifs have been at least $2220 \mathrm{~m}$ high at $6.5 \mathrm{Ma}$ (option A) or $2500 \mathrm{~m}$ high at $6.1 \mathrm{Ma}$ (option B) (Fig. 7).

\section{Discussion and concluding remarks}

The considerable interest of this case study is the presence in a small area of three chronologically distinct plant records. On this basis, it is possible to emphasise some concepts that can be considered objectively as robust outcomes:

- the Cerdanya Basin was a low altitude area during the early Tortonian as indicated by the substantial diversity of mega-mesothermic plants it sustained. Indeed it probably corresponds to the option proposed by Dèzes et al. (2004) in their reconstruction of the European Cenozoic rift system using several maps distributed through the time, even if the authors did not clearly express this assumption;

- Cerdanya was at that time surrounded by already significantly elevated massifs because its deposits contain frequent to abundant Abies pollen grains. This interpretation is supported by the rare occurrence of Picea pollen (a taxon able to withstand colder conditions than Abies; Noirfalise et al., 1987) in the Can Vilella younger pollen assemblage. This observation agrees with a probable uplift between 11-9 and ca. $6 \mathrm{Ma}$;

- the existence of an already elevated Canigou Mount in the earliest Pliocene, an observation based on the high frequency of Abies and Picea pollen in Le Boulou sequence.

Even if the numerical values obtained are questionable, a reconstructed uplift of the eastern Pyrenees since $10 \mathrm{Ma}$ is proposed. In particular the preferred option B seems sufficiently realistic to initiate new questions or re-open previous discussions (Fig. 8). Indeed, this option, the chronology of which is supported by the clarified age of Can Vilella (Gómez Cano et al., 2011), records a continuum in the uplifting process and rate. It also negates the hypothesis suggested by Agusti et al. (2006) which contradicts the evidence indicated by pollen data. It seems that an important difference in altitude between the Cerdanya Basin and the surrounding massifs already occurred in the Late Miocene time and that the eastern Pyrenees structural block continued to uplift continuously since $10 \mathrm{Ma}$, its rate ranging from 0.06 to $0.12 \mathrm{~mm} / \mathrm{yr}$. These results contrast with the previous hypotheses of topography acquisition in the eastern Pyrenees (Quaternary activity of normal faults: Briais et al., 1990; Quaternary activity of reverse faults: Philip et al., 1992; uplifted peneplain since the Late Miocene and subsequently eroded: Gunnell et al., 2010).

Concerning the palaeoaltitude estimation for the Canigou Mount, the method presented in this paper is based on the modern distribution of the Abies - Picea vegetation belt following the latitudinal and altitudinal thermal gradients. The distribution is somewhat crude since it depends on several parameters, such as exposure to sun, wind, soil, competition and, of course, of human activity. These trees may obviously develop at lower altitudes under favourable environmental conditions. However, the vegetation and the climate reconstructed for the eastern Pyrenees during the earliest Pliocene is very similar to that today in China at around $25^{\circ} \mathrm{N}$ latitude. Here, vegetation is organised into distinct vegetation belts (Fig. 7) and provides an idea of how the Pliocene vegetation in southern Europe could have been organised, according to altitude and latitude. In this modern southern Chinese vegetation organisation, Abies is found at high altitude, not below $1800 \mathrm{~m}$ (Wang, 1961; Zheng, 2000) (Fig. 7). Moreover, in the earliest Pliocene, the Roussillon shoreline occurred immediately at the foot of the mountains that significantly restricted the coastal plain width (Clauzon et al., 1990; Bache et al., 2011). Numerous low altitude taxa are recorded in the Le Boulou pollen 
assemblage. These taxa certainly colonised the slopes up to the mid-altitude, a situation that might have constrained Abies to very high altitude sites.

The presence of pollen grains of Abies in coastal marine sediments does not imply the presence of fir at low altitude. The present-day Grand Rhône prodeltaic sediments contain rare Abies pollen grains $(<2 \%$; Beaudouin et al., 2005), while the distance of the nearest populations exceeds $170 \mathrm{~km}$ (Fauquette et al., 1999). Modern pollen spectra from the eastern Pyrenees show the presence of pollen grains of Abies (Picea is not present today in the Pyrenean Mountains; Gaussen et al., 1972) in samples collected using the Cour's (1974) method (see above) from low- to mid- altitude sites at the foot of the Canigou Mount: (1) in the Mediterranean sclerophyllous vegetation (Ile sur Têt, $42^{\circ} 40^{\prime} \mathrm{N}-2^{\circ} 37^{\prime} \mathrm{E}$, at $270 \mathrm{~m}$ a.s.1.; cf.: Supplementary data 1 and 2); (2) in the Quercus pubescens belt immediately beneath the lower limit of the beech series (Mosset, $42^{\circ} 41^{\prime} \mathrm{N}-2^{\circ} 19^{\prime} \mathrm{E}$, at $900 \mathrm{~m}$ a.s.l.; cf.: Supplementary data 1 and 2). Thus, taking into account the pollen assemblages from Le Boulou, Abies should occur at high rather than at low- to mid- altitudes.

The method presented here does not aim to determine exact values for palaeoaltitudes because many uncertainties bias the results. The target is to try to give an idea of the existence or not of distinct relief and about its elevation at a given time. Comparison of reconstructed elevations at various times (including the present day) provides information concerning the tendency of evolution of the massifs (the continuing or relaxing uplift process, and the importance of erosion). Setting aside these uncertainties in relation to the MAT estimation, quantification of palaeoaltitude of uplifted sedimentary basins, such as the Cerdanya, provides relatively direct information although it is not possible to determine palaeoaltitude of the nearby summits. Palaeoaltitude of the latter can be approached through estimation of the palaeoaltitude of the base of the highest forest belt, the Abies - Picea belt in the case of this study. However, the approach presented here is highly indirect for determining palaeoaltitude of the massif concerned because: (1) it only indicates a minimum elevation of the relief, and (2) the difference from the actual palaeoaltitude cannot be evaluated. Indeed, if the forest culminated at the highest point reached by a massif, the difference could be relatively limited (some tens metres) to moderate (up to $500 \mathrm{~m}$, i.e. the width of the Abies - Picea belt; Fig. 9). Unfortunately, this matter cannot be resolved using pollen evidence. In addition, if an herbaceous belt covers the most elevated part of the massif, this difference is significantly increased because pollen analysis has yet to effectively detect such an alpine vegetation belt. Finally, this difference is further exacerbated where the summit was continuously covered by ice.

In this study the same lapse rate as today in Europe was used, i.e. $0.55^{\circ} \mathrm{C}$ per $100 \mathrm{~m}$ in altitude. However, it should be noted that the terrestrial lapse rate may vary according to several factors such as atmospheric conditions, moisture, topography, season and continentality. In the example given here, continentality would not have modified the lapse rate since all the sites selected generally occurred in similar geographic conditions influenced by the nearby Mediterranean Sea. Topography may also be an important influence on the lapse rate. Since the palaeotopography of the region was not known a priori, it is impossible to determine its influence on the lapse rate, but the conclusion of an almost constant altitudinal shift between the localities studied and the surrounding massifs (Fig. 8) allowed such an effect to be set aside. Another factor leading to different lapse rates is the air moisture. A moist adiabatic lapse rate is close to $0.5^{\circ} \mathrm{C}$ per $100 \mathrm{~m}$, when the air is saturated, whereas the dry adiabatic lapse rate is $1^{\circ} \mathrm{C}$ per $100 \mathrm{~m}$ if the air is unsaturated. During the Neogene periods studied, the climate was warm and humid. This indicated more or less saturated air conditions and thus a lapse rate of $c a .0 .5^{\circ} \mathrm{C}$ per $100 \mathrm{~m}$. As a consequence, the average value established by Ozenda $(1975,1989)$ for Europe may be used in such studies with some caution. 


\section{Acknowledgements}

This work is a contribution to ANR 'ERD-Alps' (Erosion et Evolution du Relief dans les Alpes occidentales) Project for its methodological aspects and to ANR 'PYRAMID' Project for its results, to CNRS/INSU 'Actions Marges' Project (AMEDITER), and to 'Bassins néogènes et manteau en Méditerranée' (TerMEx CNRS/INSU). We thank F. Mouthereau for his encouraging review of the manuscript. We particularly acknowledge the Editor A.P. Kershaw, S. Leroy and an anonymous referee for their review and their pertinent comments that encouraged us to improve significantly the manuscript. We are indebted to Professor Philip Gibbard who made the English revision of the manuscript. This paper is ISEM contribution $\mathrm{n}^{\circ} 2011-160$.

\section{References}

Aguilar, J.-P., Berggren, W.A., Aubry, M.-P., Kent, D.V., Clauzon, G., Benammi, M., Michaux, J., 2004. Mid-Neogene Mediterranean marine-continental correlations : an alternative interpretation. Palaeogeography, Palaeoclimatology, Palaeoecology, 204, 165186.

Aguilar, J.-P., Michaux, J., 1987. Essai d'estimation du pouvoir séparateur de la méthode biostratigraphique des lignées évolutives chez les rongeurs néogènes. Bulletin de la Société géologique de France, ser. 8, 2, 6, 1113-124.

Agustí, J., Cabrera, L., Garcés, M., Krijgsman, W., Oms, O., Parés, J.M., 2001. A calibrated mammal scale for the Neogene of Western Europe. State of the art. Earth-Science Review, $52,247-260$.

Agustí, J., Oms, O., Furió, M., Pérez-Vila, M.-J., Roca, E., 2006. The Messinian terrestrial record in the Pyrenees: The case of Can Vilella (Cerdanya Basin). Palaeogeography, Palaeoclimatology, Palaeoecology, 238, 179-189.

Agustí, J., Roca, E., 1987. Sintesis biostratigrafica de la fosa de la Cerdanya (Pirineos orientales). Estudios geológicos, 43, 521-529.

Arthaud, F., Matte, P., 1975. Les décrochements tardihercyniens du SW de l'Europe, géométrie et essai de reconstitution des conditions de la déformation. Tectonophysics, 25, 139-171.

Axelrod, D.I., 1965. A method for determining the altitudes of Tertiary floras. Paleobotanist, $14,144-171$.

Axelrod, D.I., 1968. Tertiary Floras and Topographic History of the Snake River Basin, Idaho. Geological Society of America Bulletin, 79, 713-734.

Axelrod, D.I., 1997. Paleoelevation Estimated from Tertiary Floras. International Geology Review, 39, 1124-1133.

Axelrod, D.I., Bailey, H.P., 1976. Tertiary vegetation, climate and altitude of the Rio Grande depression, New Mexico-Colorado. Paleobiology, 2, 235-254.

Babault, J., Van Den Driessche, J., Bonnet, S., Castelltort, S., Crave, A., 2005. Origin of the highly elevated Pyrenean peneplain. Tectonics, 24, TC2010, doi:10.1029/2004TC001697, $19 \mathrm{p}$.

Bache, F. Popescu, S.-M., Rabineau, M., Gorini, C., Suc, J.-P., Clauzon, G., Olivet, J.-L., Rubino, J.-L., Melinte-Dobrinescu, M.C., Estrada, F., Londeix, L., Armijo, R., Meyer, B., Jolivet, L., Jouannic, G., Leroux, E., Aslanian, D., Dos Reis, A.T., Mocochain, L., Dumurdžanov, N., Zagorchev, I., Lesić, V., Tomić, D., Çağatay, M.N., Brun, J.-P., Sokoutis, D., Csato, I., Ucarkus, G., Çakir, Z., 2011. A two-step process for the reflooding of the 
Mediterranean after the Messinian Salinity Crisis. Basin Research, 23, 1-29, doi: 10.1111/j.1365-2117.2011.00521.

Bachiri Taoufiq, N., Barhoun, N., Suc, J.-P., 2008. Les environnements continentaux du corridor rifain (maroc) au Miocène supérieur d'après la palynologie. Geodiversitas, 30, 4158.

Beaudouin, C., Suc, J.-P., Cambon, G., Touzani, A., Giresse, P., Pont, D., Aloïsi, J.-C., Marsset, T., Cochonat, P., Duzer, D., Ferrier, J., 2005. Present-day rhythmic deposition in the Grand Rhône prodelta (NW Mediterranean) according to high-resolution pollen analyses. Journal of Coastal Research, 21, 2, 292-306.

Bessedik, M., 1985. Reconstitution des environnements miocènes des régions nord-ouest méditerranéennes à partir de la palynologie. Thesis, Univ. Montpellier 2, 162 p.

Briais, A., Armijo, R., Winter, T., Tapponnier, P., Herbecq, A., 1990. Morphological evidence for Quaternary normal faulting and seismic hazard in the eastern Pyrenees. Annales Tectonicae, 4, 1, 19-42.

Cabrera, L., Roca, E., Santanach, P., 1988. Basin formation at the end of a strike-slip fault: the Cerdanya basin (eastern Pyrenees). Journal of the Geological Society, London, 145, 2, 261-268.

Chamberlain, C.P., Poage, M.A., 2000. Reconstructing the paleotopography of mountain belts from the isotopic composition of authigenic minerals. Geology, 28, 2, 115-118.

Clauzon, G., 1990. Restitution de l'évolution géodynamique néogène du bassin du Roussillon et de l'unité adjacente des Corbières d'après les données écostratigraphiques et paléogéographiques. Paléobiologie continentale, 17, 125-155.

Clauzon, G., Suc, J.-P., Aguilar, J.-P., Ambert, P., Cappetta, H., Cravatte, J., Drivaliari, A., Doménech, R., Dubar, M., Leroy, S., Martinell, J., Michaux, J., Roiron, P., Rubino, J.-L., Savoye, B., Vernet, J.-L., 1990. Pliocene geodynamic and climatic evolutions in the French Mediterranean region. Paleontologia i Evolucio, Spec. Mem., 2, 132-186.

Coney, P.J., Muñoz, A., McClay, K.R., Evenchick, C.A., 1996. Syntectonic burial and posttectonic exhumation of the southern Pyrenees foreland fold-thrust belt. Journal of the Geological Society, London, 153, 9-16.

Cour, P., 1974. Nouvelles techniques de détection des flux et des retombées polliniques: étude de la sédimentation des pollens et des spores à la surface du sol. Pollen et Spores, 16, 1, $103-141$.

Cravatte, J., Matias, I., Suc, J.-P., 1984. Nouvelles recherches biostratigraphiques sur le Pliocène du Roussillon. Géologie de la France, 1-2, 149-163.

Dèzes, P., Schmid, S.M., Ziegler, P.A., 2004. Evolution of the European Cenozoic Rift System: interaction of the Alpine and Pyrenean orogens with their foreland lithosphere. Tectonophysics, 389, 1-33.

Fauquette, S., Bertini, A., 2003. Quantification of the northern Italy Pliocene climate from pollen data: evidence for a very peculiar climate pattern. Boreas, 32, 361-369.

Fauquette, S., Clauzon, G., Suc, J.-P., Zheng, Z., 1999. A new approach for palaeoaltitude estimates based on pollen records: example of the Mercantour Massif (southeastern France) at the earliest Pliocene. Earth Planetary and Science Letters, 170, 35-47.

Fauquette, S., Guiot, J., Suc, J.-P., 1998. A method for climatic reconstruction of the Mediterranean Pliocene using pollen data. Palaeogeography, Palaeoclimatology, Palaeoecology, 144, 183-201.

Fauquette, S., Suc, J.-P., Bertini, A., Popescu, S.-M., Warny, S., Bachiri Taoufiq, N., Perez Villa, M.-J., Chikhi, H., Subally, D., Feddi, N., Clauzon, G., Ferrier, J., 2006. How much did climate force the Messinian salinity crisis? Quantified climatic conditions from pollen records in the Mediterranean region. Palaeogeography, Palaeoclimatology, Palaeoecology, $238,281-301$. 
Fauquette, S., Suc, J.-P., Jiménez-Moreno, G., Micheels, A., Jost, A., Favre, E., BachiriTaoufiq, N., Bertini, A., Clet-Pellerin, M., Diniz, F., Farjanel, G., Feddi, N., Zheng, Z., 2007. Latitudinal climatic gradients in Western European and Mediterranean regions from the Mid-Miocene (c. $15 \mathrm{Ma}$ ) to the Mid-Pliocene (c. 3.5 Ma) as quantified from pollen data. In: Williams M., Haywood A., Gregory J., Schmidt D.N. (Eds.), Deep-Time Perspectives on Climate Change. Marrying the Signal from Computer Models and Biological Proxies. The Micropaleontological Society, The Geological Society, London, Special Publications, 481502.

Favre, E., 2007. Evolution de la vegetation de l'Europe et du pourtour méditerranéen au Néogène dans les contexts climatique global et géographique regional. Approches statistiques et élaboration de cartes de végétation à partir des données polliniques. $\mathrm{PhD}$ Thesis, Univ. Granada and Univ. C. Bernard - Lyon 1, 262 p.

Fitzgerald, P.G., Muñoz, J.A., Coney, P.J., Baldwin, S.L., 1999. Asymmetric exhumation across the Pyrenean orogen: implications for the tectonic evolution of a collisional orogen. Earth Planetary Science Letters, 173, 157-170.

François, L., Utescher, T., Favre, E., Henrot, A.-J., Warnant, P., Micheels, A., Erdei, B., Suc, J.-P., Cheddadi, R., Mosbrugger, V., 2011. Modelling Late Miocene vegetation in Europe: Results of the CARAIB model and comparison with palaeovegetation data. Palaeogeography, Palaeoclimatology, Palaeoecology, 304, 359-378.

Gaussen, H., 1972. Les cartes de vegetation dans le basin de l'Ebre. Pirineos, 105, 69-83.

Gaussen, H., Conill, M., Mestre, L., Rey, P., Combrade, G., Dupias, G., Lacaze, D., Sajus, J., Izard, M., Lacassin, M., Mazars, M., Nayme, C., 1972. Carte de la végétation de la France. 78, Perpignan. Service de la Carte de la Végétation, C.N.R.S., Toulouse.

Gómez Cano, A.R., Hernández Fernández, M., Álvarez-Sierra, M.A., 2011. Biogeographic provincialism in rodent faunas from the Iberrocitanian Region (southwestern Europe) generates severe diachrony within the Mammalian neogene $(\mathrm{MN})$ biochronologic scale during the Late Miocene. Paleogeography, Palaeoclimatology, Palaeoecology, 307, 193204.

Gorini, C., Le Marrec, A., Mauffret, A., 1993. Contribution to the structural and sedimentary history of the gulf of Lions (western Mediterranean), from the ECORS profiles, industrial seismic profiles and well data. Bulletin de la Société géologique de France, 164, 3, 353363.

Gruber, M., 1980. Dissymétrie climatique et forestière dans les Pyrénées. Forêt méditerranéenne, 1, 2, 135-140.

Gunnell, Y., 2000. Apatite fission track thermochronology: an overview of its potential and limitations in geomorphology. Basin Research, 12, 115-132.

Gunnell, Y., Calvet, M., Brichau, S., Carter, A., Aguilar, J.-P., Zeyen, H., 2009. Low longterm erosion rates in high-energy mountain belts: Insights from thermo- and biochronology in the Eastern Pyrenees. Earth and Planetary Science Letters, 278, 208-218.

Haywood, A. M., Sellwood, B. W., Valdes, P. J., 2000a. Regional warming: Pliocene (3 Ma) paleoclimate of Europe and the Mediterranean. Geology, 28, 1063-1066.

Haywood, A. M., Valdes, P. J., Sellwood, B.W., 2000b. Global scale palaeoclimate reconstruction of the middle Pliocene climate using the UKMO CGM: initial results. Global and Planetary Change, 25, 239-256.

Huyghe D., Mouthereau F., Castelltort S., Filleaudeau P.Y., Emmanuel L., 2009. Paleogene propagation of the southern Pyrenean thrust wedge revealed by finite strain analysis in frontal thrust sheets: Implications for mountain building. Earth and Planetary Science Letters, 288, 421-433. 
Jiménez-Moreno, G. 2005. Utilización del análisis polínico para la reconstrucción de la vegetación, clima y estimación de paleoaltitudes a lo largo de arco alpino europeo durante el Mioceno (21-8 m.a.). PhD Thesis, Univ. Granada and Univ. C. Bernard - Lyon 1, 318 p.

Jiménez-Moreno, G., Fauquette, S., Suc, J.-P., 2008. Vegetation, climate and palaeoaltitude reconstructions of the Eastern Alps during the Miocene based on pollen records from Austria, Central Europe. Journal of Biogeography, 35, 1638-1649.

Jiménez-Moreno, G., Fauquette, S., Suc, J.-P., Abdul Aziz, H., 2007b. Early Miocene repetitive vegetation and climatic changes in the lacustrine deposits of the Rubielos de Mora Basin (Teruel, NE Spain). Paleogeography, Palaeoclimatology, Palaeoecology, 250, 101113.

Jiménez-Moreno, G., Popescu, S.-M., Ivanov, D., Suc, J.-P., 2007a. Neogene flora, vegetation and climate dynamics in Central Eastern Europe according to pollen records. In: Williams, M., Haywood, A., Gregory, J., Schmidt, D.N. (Eds.), Deep-Time Perspectives on Climate Change. Marrying the Signal from Computer Models and Biological Proxies, The Micropaleontological Society, The Geological Society, London, Special Publications, 393406.

Jiménez-Moreno, G., Rodríguez-Tovar, F.-J., Pardo-Igúzquiza, E., Fauquette, S., Suc, J.-P., Müller, P., 2005. High-resolution palynological analysis in late early-middle Miocene core from the Pannonian Basin, Hungary: climatic changes, astronomical forcing and eustatic fluctuations in the Paratethys. Paleogeography, Palaeoclimatology, Palaeoecology, 216, 12, 73-97.

Jiménez-Moreno, G., Suc, J.-P., 2007. Middle Miocene latitudinal climatic gradient in Western Europe: Evidence from pollen records. Palaeogeography, Palaeoclimatology, Palaeoecology, 253, 224-241.

Jiménez-Moreno, G., Suc, J.-P., Fauquette, S., 2010. Miocene to Pliocene vegetation reconstruction and climate estimates from the Iberian Peninsula from pollen data. Review of Palaeobotany and Palynology, 162, 403-415.

Jost, A., Fauquette, S., Kageyama, M., Krinner, G., Ramstein, G., Suc, J.-P., Violette, S., 2009. High resolution climate and vegetation simulations of the Mid-Pliocene, a model-data comparison over western Europe and the Mediterranean region. Climate of the Past, 5, 585606.

Khondkarian, S.O., Shcherba I.G., Popov, S.V., Gürs, K., Iosifova, J.I., Jakubovskaja, T.V., Kovac, M., Magyar, I., Pinchuk, T.N., Zastrozhnov, A.S., 2004. Map 9: Latest Miocene. In: Popov, S.V., Rögl, F., Rozanov, A.Y., Steininger, F.F., Shcherba, I.G., Kovac, M. (Eds.), Lithological-Paleogeographic maps of Paratethys. Courier Forschungsinstitut Senckenberg, 250, 35-37.

Klotz, S., Fauquette, S., Combourieu-Nebout, N., Uhl, D., Suc, J.-P., Mosbrugger, V., 2006. Seasonality intensification and long-term winter cooling as a part of the Late Pliocene climate development. Earth and Planetary Science Letters, 241, 174-187.

Kooi, H., Beaumont, C., 1996. Large-scale geomorphology: Classical concepts reconciled and integrated with contemporary ideas via a surface processes model. Journal of Geophysical Research, 101, B2, 3361-3386.

Krijgsman, W., 2002.The Mediterranean: Mare Nostrum of Earth Sciences. Earth and Planetary Science Letters, 205, 1-12.

Mauffret, A., Durand de Grossouvre, B., Dos Reis, A.T., Gorini, C., Nercessian, A., 2001. Structural geometry in the eastern Pyrenees and western Gulf of Lion (Western Mediterranean). Journal of Structural Geology, 23, 1701-1726.

Maurel, O., Brunel, M., Monié, P., 2002. Exhumation cénozoïque des massifs du Canigou et de Mont-Louis (Pyrénées orientales, France). Comptes Rendus Geoscience, 334, 941-948. 
Menéndez Amor, J., 1955. La depressión Ceretana española y sus vegetales fósiles. Característica fitopaleontológica del Neógeno de la Cerdaña española. Memorias de la Real Academia de Ciencias exactas, físicas y naturales de Madrid, ser. Ciencias Nat., 18, 1-344.

Meulenkamp, J.E., Sissingh, W., 2003. Tertiary palaeogeography and tectonostratigraphic evolution of the Northern and Southern Peri-Tethys platforms and the intermediate domains of the African-Eurasian convergent plate boundary zone. Palaeogeography, Palaeoclimatology, Palaeoecology, 196, 209-228.

Meyer, H.W., 1992. Lapse rates and other variables applied to estimating paleoaltitudes from fossil floras. Palaeogeography, Palaeoclimatology, Palaeoecology, 99, 71-99.

Mulch, A., Teyssier, C., Cosca, M.A., Vanderhaeghe, O., Vennemann, T.W., 2004. Reconstructing paleoelevation in eroded orogens. Geology, 32, 525-528.

Muñoz J.A., 1992. Evolution of a Continental Collision Belt: ECORS-Pyrenees Crustal Balanced Cross-section. In: K.R. McClay, Editor, Thrust Tectonics, Chapman and Hall, 235-246.

Nix, H., 1982. Environmental determinants of biogeography and evolution in Terra Australis. In: Barker, W.R., Greenslade, P.J.M. (Eds.), Evolution of the Flora and fauna of Arid Australia. Peacock Publishing, Frewville, 47-66.

Noirfalise, A., Dahl, E., Ozenda, P., Quézel, P., 1987. Carte de la végétation naturelle des états membres des communautés européennes et du conseil de l'Europe. Office des publications officielles des Communautés européennes, Luxembourg, $78 \mathrm{pp}$.

Olivera C., Redondo E., Lambert J., Riera-Melis A., Roca A., 2008. Review of Historical Earthquakes in the Lower Middle Ages: Earthquakes of the XIV and XV Centuries in Catalonia (NE Spain). Historical Seismology, Modern Approaches in Solid Earth Sciences, Vol. 2, Part II, 147-162.

Olivet, J.-L., 1996. La cinématique de la plaque ibérique. Bulletin des Centres de Recherche Exploration-Production Elf-Aquitaine, 20, 131-195.

Ozenda, P., 1975. Sur les étages de végétation dans les montagnes du bassin méditerranéen. Documents de Cartographie Ecologique, 16, 1-32.

Ozenda, P., 1989. Le déplacement vertical des étages de végétation en fonction de la latitude: un modèle simple et ses limites. Bulletin de la Société géologique de France, ser. 8, 5,3, 535-540.

Ozenda, P., 2002. Perspectives pour une géobiologie des montagnes. Presses polytechniques et universitaires romandes, Lausanne, $195 \mathrm{pp}$.

Paramonova, N.P., Shcherba I.G., Khondkarian, S.O., Gürs, K., Iosifova, J.I., Jakubovskaja, T.V., Kovac, M., Magyar, I., Pinchuk, T.N., Popov, S.V., Zastrozhnov, A.S., 2004. Map 7: Late Middle Miocene. In: Popov, S.V., Rögl, F., Rozanov, A.Y., Steininger, F.F., Shcherba, I.G., Kovac, M. (Eds.), Lithological-Paleogeographic maps of Paratethys. Courier Forschungsinstitut Senckenberg, 250, 27-29.

Philip, H., Bousquet, J.-C., Escuer, J., Fleta, J., Goula, X., Grellet, B., 1992. Présence de failles inverses d'âge quaternaire dans l'Est des Pyrénées : implications sismotectoniques. Comptes-Rendus de l'Académie des Sciences de Paris, ser. 2, 314, 1239-1244.

Popescu, S.-M., 2001. Repetitive changes in Early Pliocene vegetation revealed by highresolution pollen analysis: revised cyclostratigraphy of southwestern Romania. Review of Palaeobotany and Palynology, 120, 181-202.

Popescu, S.-M., 2006. Late Miocene and early Pliocene environments in the southwestern Black Sea region from high-resolution palynology of DSDP Site 380A (Leg 42B). Palaeogeography, palaeoclimatology, Palaeoecology, 238, 64-77.

Popescu, S.-M., Biltekin, D., Winter, H., Suc, J.-P., Melinte-Dobrinescu, M.C., Klotz, S., Combourieu-Nebout, N., Rabineau, M., Clauzon, G., Deaconu, F., 2010. Pliocene and 
Lower Pleistocene vegetation and climate changes at the European scale: Long pollen records and climatostratigraphy. Quaternary International, 219, 152-167.

Popescu, S.-M., Krijgsman, W., Suc, J.-P., Clauzon, G., Mărunțeanu, M., Nica, T., 2006. Pollen record and integrated high-resolution chronology of the Early Pliocene Dacic Basin (Southwestern Romania). Palaeogeography, Palaeoclimatology, Palaeoecology, 238, 1-4, 78-90.

Pous, J., Julià, R., Solé Sugrañes, L., 1986. Cerdanya Basin geometry and its implication on the Neogene evolution of the eastern Pyrenees. Tectonophysics, 129, 355-365.

Réhault, J.-P., Boillot, G., Mauffret, A., 1984. The western Mediterranean Basin, geological evolution. Marine Geology, 55, 447-477.

Roca, E., 1996. The Neogene Cerdanya and Seu d'Urgell intramontane basins (Eastern Pyrenees). In: Friend, P.F., Dabrio, C.J. (Eds.), Tertiary Basins of Spain: The Stratigraphic Record of crustal Kinematics. Cambridge University Press, New York, 114-119.

Roest W.R., Srivastava S.P., 1991. Kinematics of the plate boundaries between Eurasia, Iberia, and Africa in the North Atlantic from the Late Cretaceous to the present. Geology, 19 (6), 613-616.

Suc, J.-P., 1976. Apports de la palynologie à la connaissance du Pliocène du Roussillon (sud de la France). Geobios, 9, 6, 741-771.

Suc, J.-P., 1989. Distribution latitudinale et étagement des associations végétales au Cénozoïque supérieur dans l'aire ouest-méditerranéenne. Bulletin de la Société géologique de France, ser. 8, 5, 3, 541-550.

Suc, J.-P., Clauzon, G., Bessedik, M., Leroy, S., Zheng, Z., Drivaliari, A., Roiron, P., Ambert, P., Martinell, J., Doménech, R., Matias, I., Julià, R., Anglada, R., 1992. Neogene and Lower Pleistocene in Southern France and Northeastern Spain. Mediterranean environments and climate. Cahiers de Micropaleontologie, 7, 1-2, 165-186.

Suc, J.-P., Bertini, A., Combourieu-Nebout, N., Diniz, F., Leroy, S., Russo-Ermolli, E., Zheng, Z., Bessais, E., Ferrier, J., 1995c. Structure of West Mediterranean vegetation and climate since 5.3 Ma. Acta zoologica cracoviense, 38, 1, 3-16.

Suc, J.-P., Clauzon, G., Bessedik, M., Leroy, S., Zheng, Z., Drivaliari, A., Roiron, P., Ambert, P., Martinell, J., Doménech, R., Matias, I., Julià, R., Anglada, R., 1992. Neogene and Lower Pleistocene in Southern France and Northeastern Spain. Mediterranean environments and climate. Cahiers de Micropaleontologie, 7, 1-2, 165-186.

Suc, J.-P., Diniz, F., Leroy, S., Poumot, C., Bertini, A., Dupont, L., Clet, M., Bessais, E., Zheng, Z., Fauquette, S., Ferrier, J., 1995b. Zanclean ( Brunssumian) to early Piacenzian ( early-middle Reuverian) climate from $4^{\circ}$ to $54^{\circ}$ north latitude (West Africa, West Europe and West Mediterranean areas). Mededelingen Rijks Geologische Dienst, 52, 43-56.

Suc, J.-P., Fauquette, S., Bessedik, M., Bertini, A., Zheng, Z., Clauzon, G., Suballyova, D., Diniz, F., Quézel, P., Feddi, N., Clet, M., Bessais, E., Bachiri Taoufiq, N., Méon, H., Combourieu-Nebout, N., 1999. Neogene vegetation changes in West European and West circum-Mediterranean areas. In: Agusti, J., Rook, L., Andrews, P. (Eds.), Hominid Evolution and Climate in Europe, 1 Climatic and Environmental Change in the Neogene of Europe, Cambridge University Press, 370-385.

Suc, J.-P., Violanti, D., Londeix, L., Poumot, C., Robert, C., Clauzon, G., Turon, J.-L., Ferrier, J., Chikhi, H., Cambon, G., Gautier, F., 1995a. Evolution of the Messinian Mediterranean environments: the Tripoli Formation at Capodarso (Sicily, Italy). Review of Palaeobotany and Palynology, 87, 51-79.

Troll, C., 1966. Ökologische Landschaftsforschung und vergleichende Hochgebirgsforschung. Franz Steiner (Ed.), Erdkundliches Wissen, Wiesbaden, 11.

Troll, C., 1973. High Mountain Belts between the Polar Caps and the Equator: Their definition and Lower Limit. Arctic and Alpine Research, 5, 19-28. 
Wang, C.W., 1961. The forest of China with a survey of Grassland and Desert vegetation, Maria Moors Cabot Foundation, publication $\mathrm{n}^{\circ} 5$, Harvard University, Cambridge, Massachusetts, 313 pp.

Westerhold, T., Bickert, T., Röhl, U., 2005. Middle to late Miocene oxygen isotope stratigraphy of ODP site 1085 (SE Atlantic): new constrains on Miocene climate variability and sea-level fluctuations. Palaeogeography, Palaeoclimatology, Palaeoecology, 217, 205222.

Wolfe, H.W., 1995. Paleoclimatic estimates from Tertiary leaf assemblages. Annual Reviews of Earth and Planetary Sciences, 23, 119-142.

Zachos, J.C., Pagani, M., Sloan, L., Thomas, E., Billups, K., 2001. Trends, Rhythms, and Aberrations in Global Climate 65 Ma to Present. Science, 292, 686-693.

Zheng, Z., 2000. Late Quaternary vegetational and climatic changes in the tropical and subtropical areas of China. Acta Micropalaeontologica Sinica, 17, 125-146. 


\section{Figure captions}
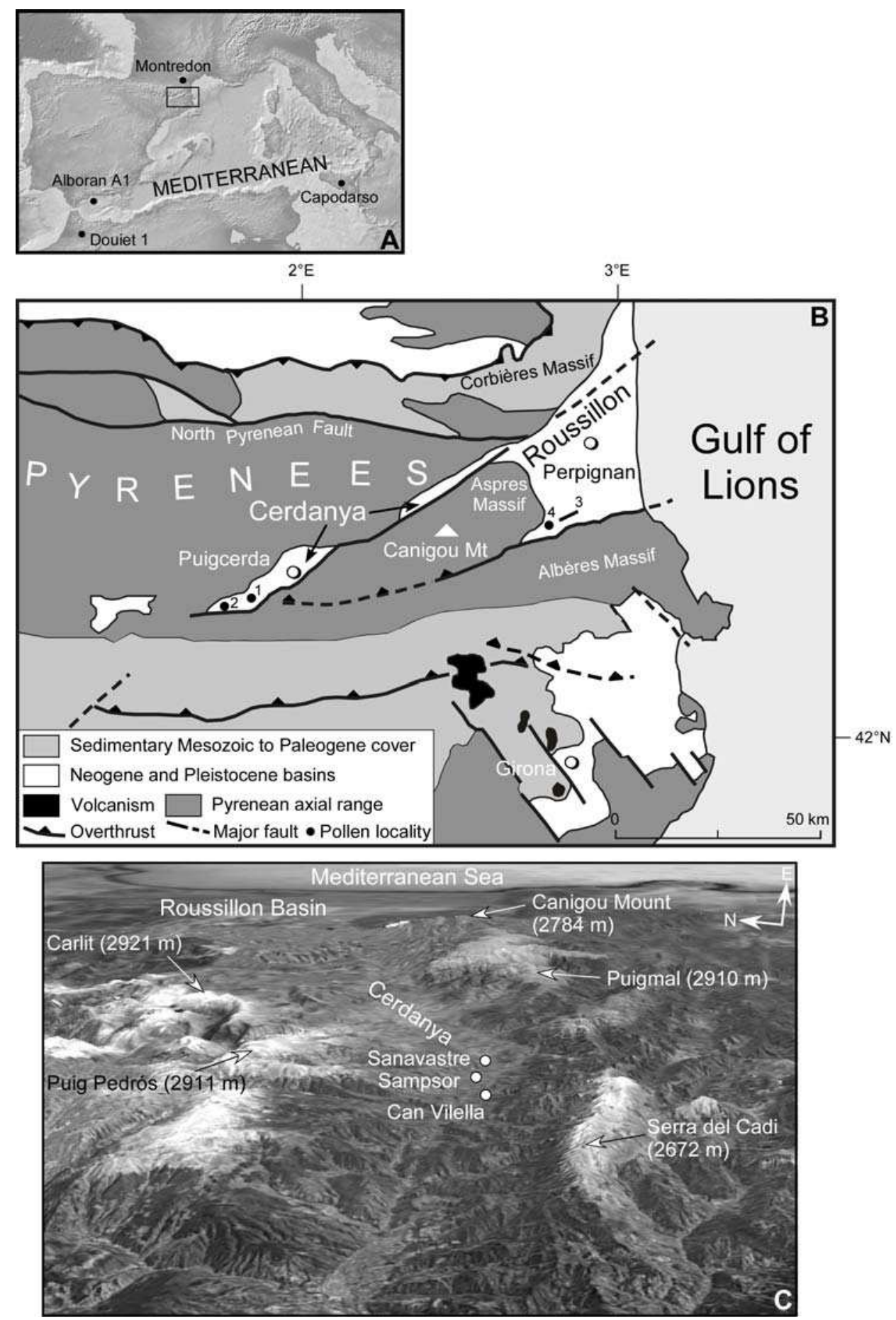

Fig. 1. Geography, geology and topography of the eastern Pyrenees.

A, Location map of the studied area showing the pollen localities considered for this climatic comparison.

B, Regional geological structure (from Briais et al., 1990).

Pollen localities: 1, Sanavastre and Sampsor; 2, Can Vilella; 3, Le Boulou; 4, Vivès.

$\mathrm{C}$, Three dimensional perspective Google Earth view showing the Cerdanya and Roussillon basins and their bordering high massifs. The distance between the foreground and Mediterranean coastline is of $c a .120 \mathrm{~km}$. 


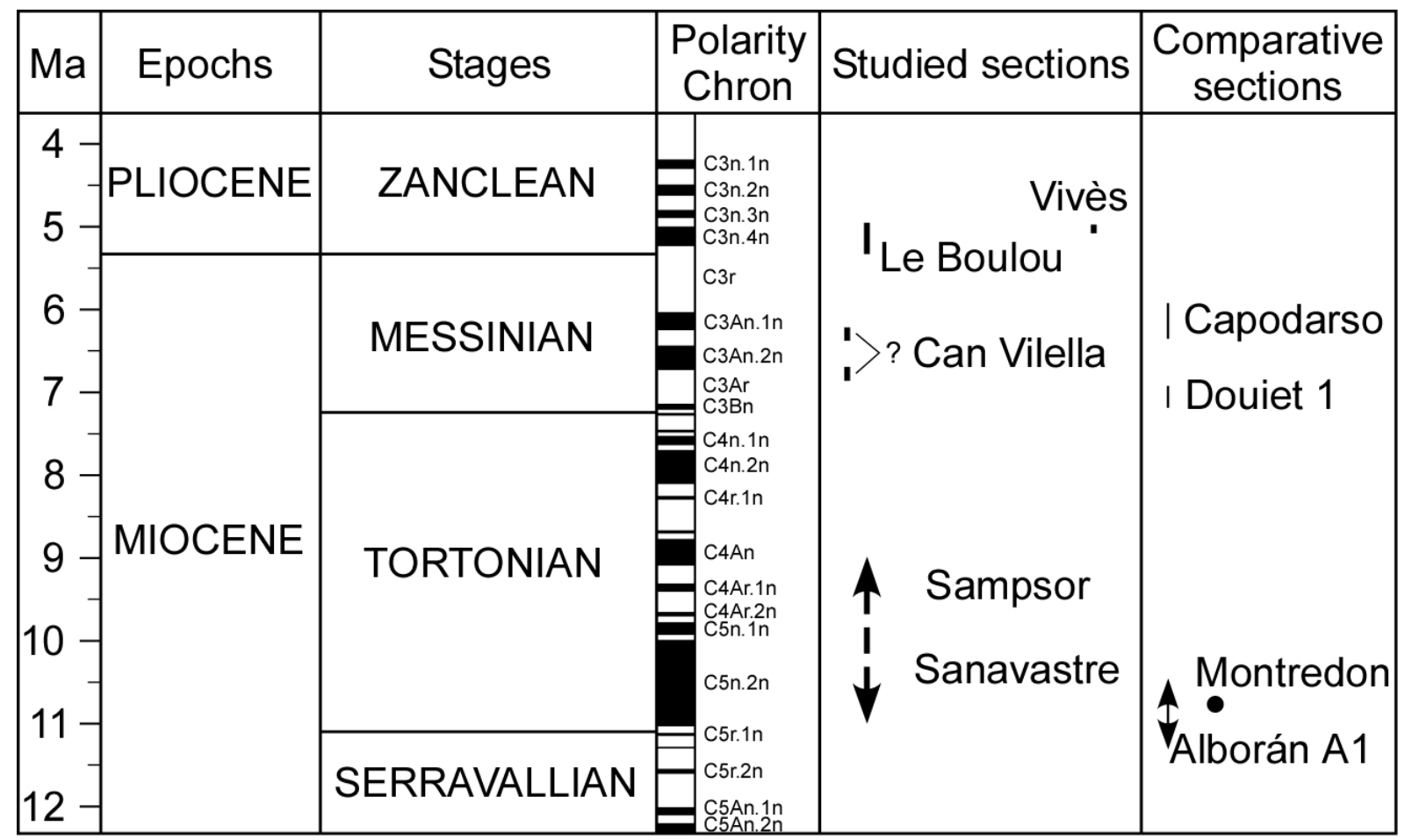

Fig. 2. Estimated chronostratigraphical position of the pollen floras studied and of the comparative pollen floras used for the palaeoaltitude reconstructions. 


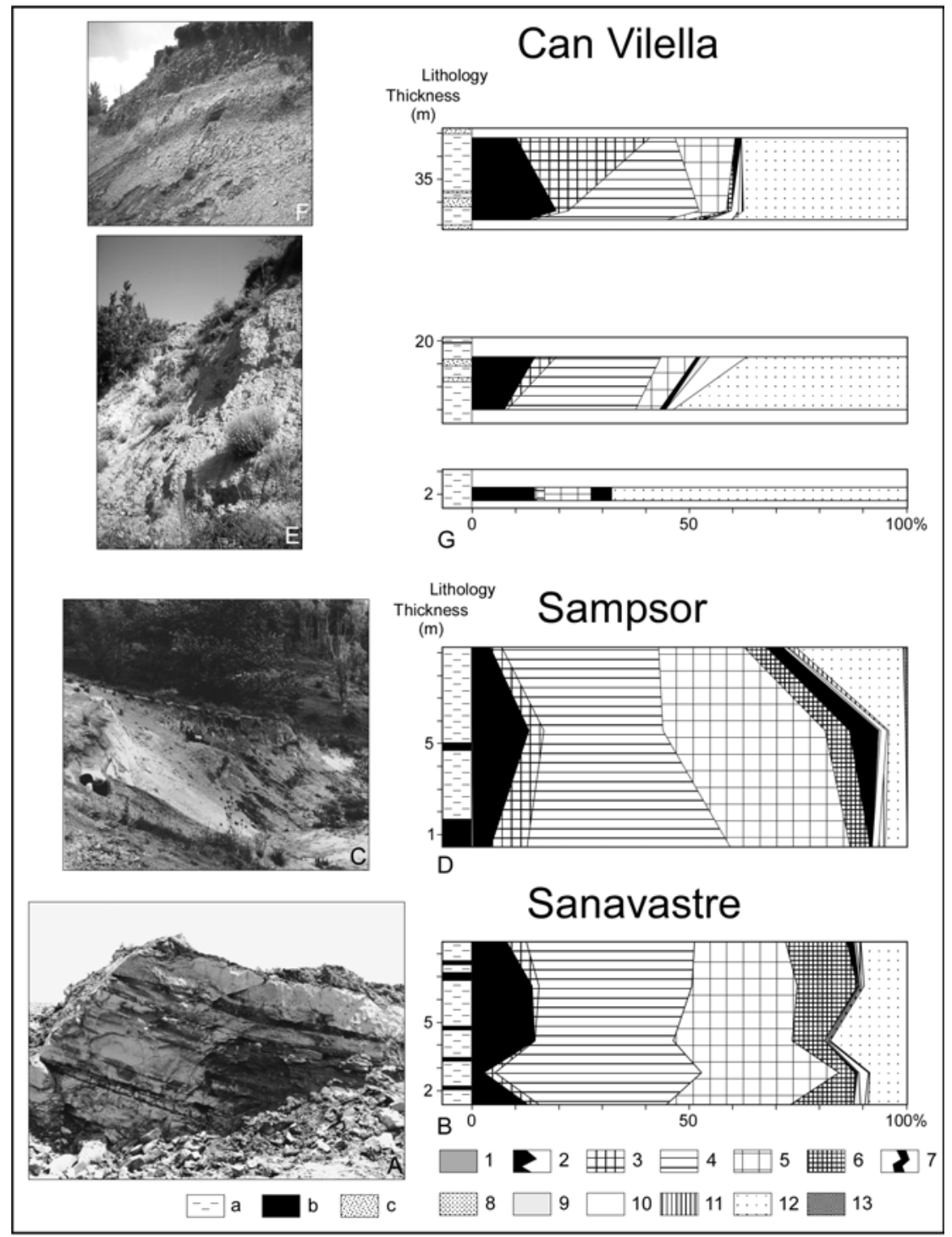

Fig. 3. Pollen localities from Cerdanya.

Sanavastre: A, View of the sampled section.

B, Synthetic pollen diagram.

Sampsor: $\quad$ C, View of the sampled section.

$\mathrm{D}$, Synthetic pollen diagram.

Can Vilella: E, View of the middle part of the section.

F, View of the upper part of the section.

G, Synthetic pollen diagram of the section in three segments, respectively located at the base, in the middle part and upper part of the section (for details, see: Agusti et al., 2006).

Lithology: a, Clay or diatomite; b, Lignite; c, Gravels.

Ecological pollen groups according to Nix (1982) for their present thermal classification: 1, Megathermic elements (MAT $>24^{\circ} \mathrm{C}$ ); 2, Mega-mesothermic elements $\left(20^{\circ} \mathrm{C}<\mathrm{MAT}<24^{\circ} \mathrm{C}\right) ; 3$, Cathaya, a conifer restricted today to the Chinese mixed deciduous forest (cf. Fig. 10); 4, Mesothermic elements $\left(14^{\circ} \mathrm{C}<\mathrm{MAT}<20^{\circ} \mathrm{C}\right) ; 5$, Pinus; 6, Meso-microthermic elements $\left(12^{\circ} \mathrm{C}<\mathrm{MAT}<14^{\circ} \mathrm{C}\right)$; 7, Microthermic elements (MAT $<12^{\circ} \mathrm{C}$ ); 8,Cupressaceae composed of elements living under various conditions; 9, Elements which cannot be used because of the insufficient level of pollen identification or their ecological ubiquity; 10, Hygrophilous plants;11, Mediterranean xerophytes; 12, Herbs; 13, Steppe elements. 


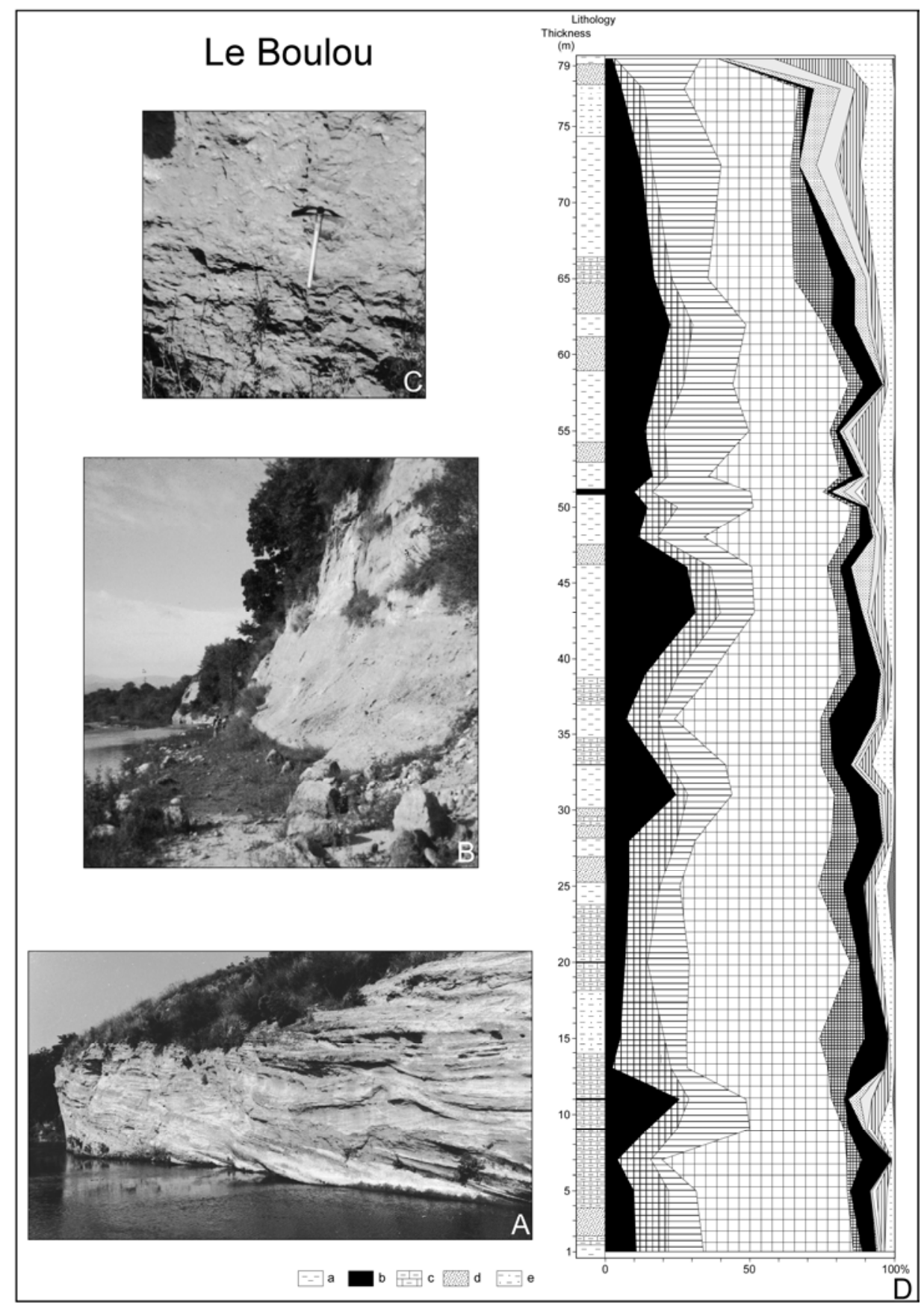

Fig. 4. Pollen locality of the Le Boulou sequence (Roussillon Basin).
A, View of the lowermost part of the section.
$\mathrm{B}$, View of the middle part of the section.
C, View of the uppermost part of the section.
$\mathrm{D}$, Synthetic pollen diagram of the section.

Lithology: a, Grey clays; b, Lignite; c, Whitish marls; d, Sands and gravels; e, Grey silts.

Ecological pollen groups: same caption for Figure 3. 


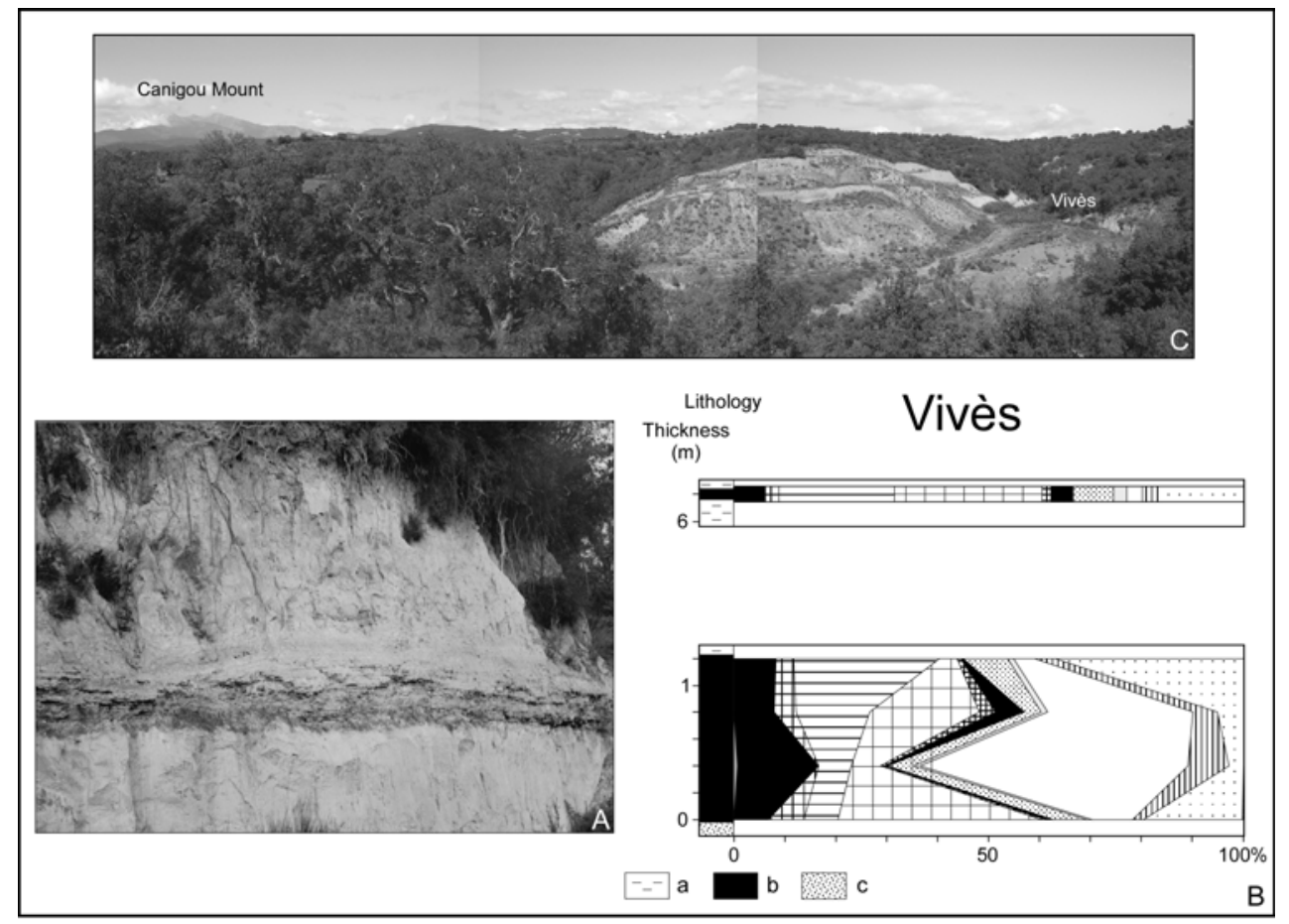

Fig. 5. Pollen locality of Vivès (Roussillon Basin).

A, View of the section.

B, Synthetic pollen diagram of the section in two segments, respectively located in the middle part and uppermost part of the section.

Lithology: a, Grey clays; b, Lignite; c, Sands and gravels.

Ecological pollen groups: same legend as Figure 3.

$\mathrm{C}$, Panorama showing the short distance from the Canigou Mount to the Vivès section.

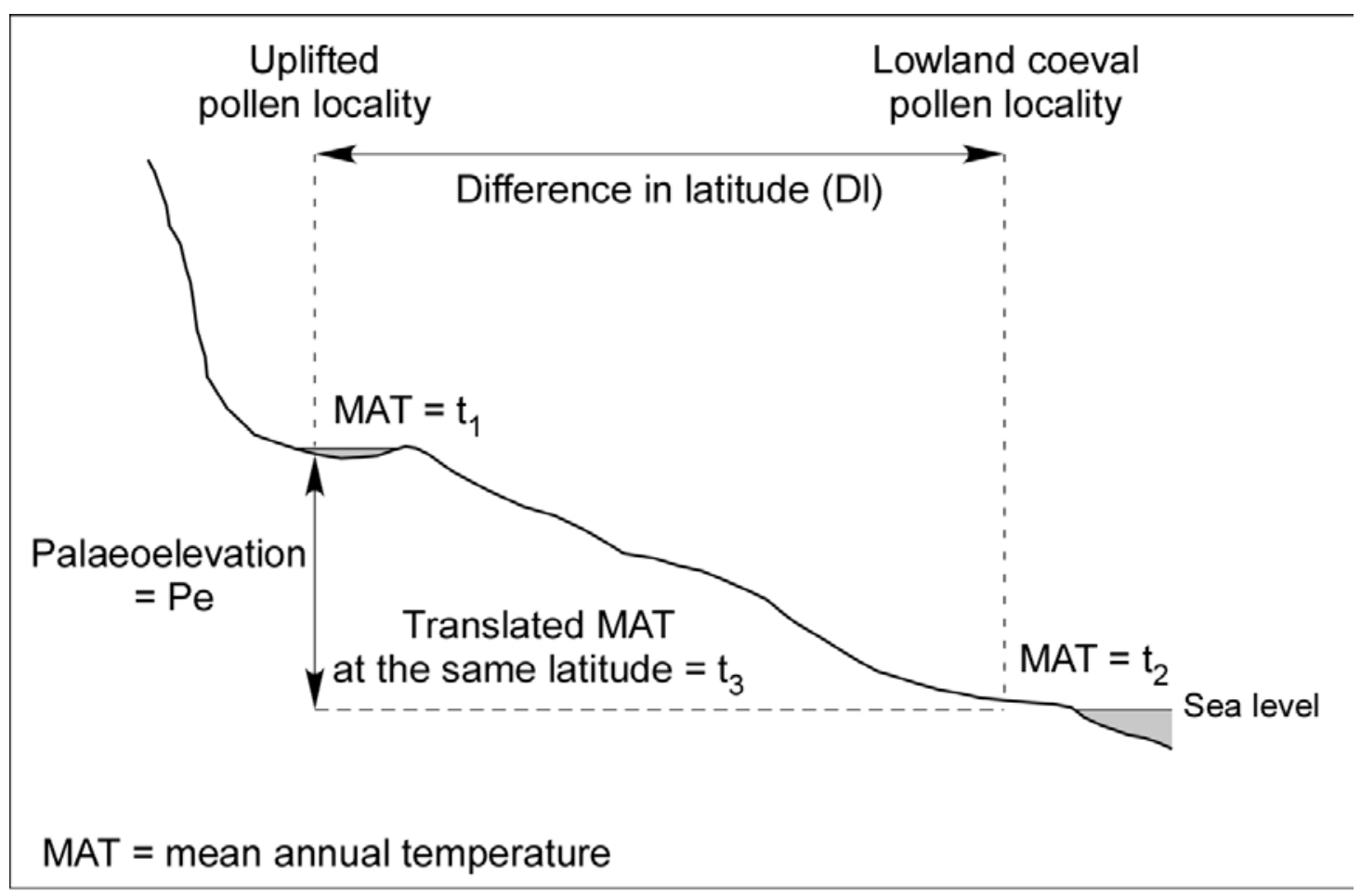

Fig. 6. Method for estimating the palaeoaltitude of an uplifted basin with the associated parameters. 


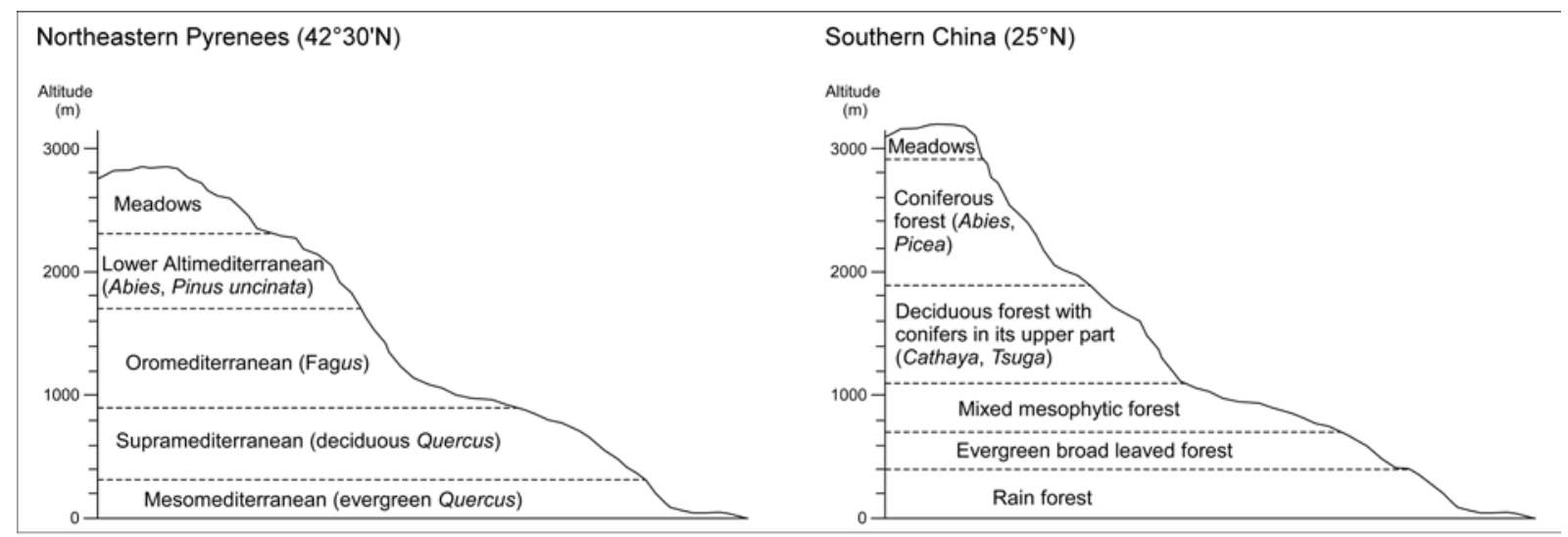

Fig. 7. Present-day compared schematic altitudinal organisation of vegetation in the northeastern Pyrenees (latitude $42^{\circ} 30^{\prime} \mathrm{N}$; Gruber, 1980), based on vegetation belts defined by Ozenda (1975) and in southern China (latitude $25^{\circ} \mathrm{N}$; Wang, 1961).

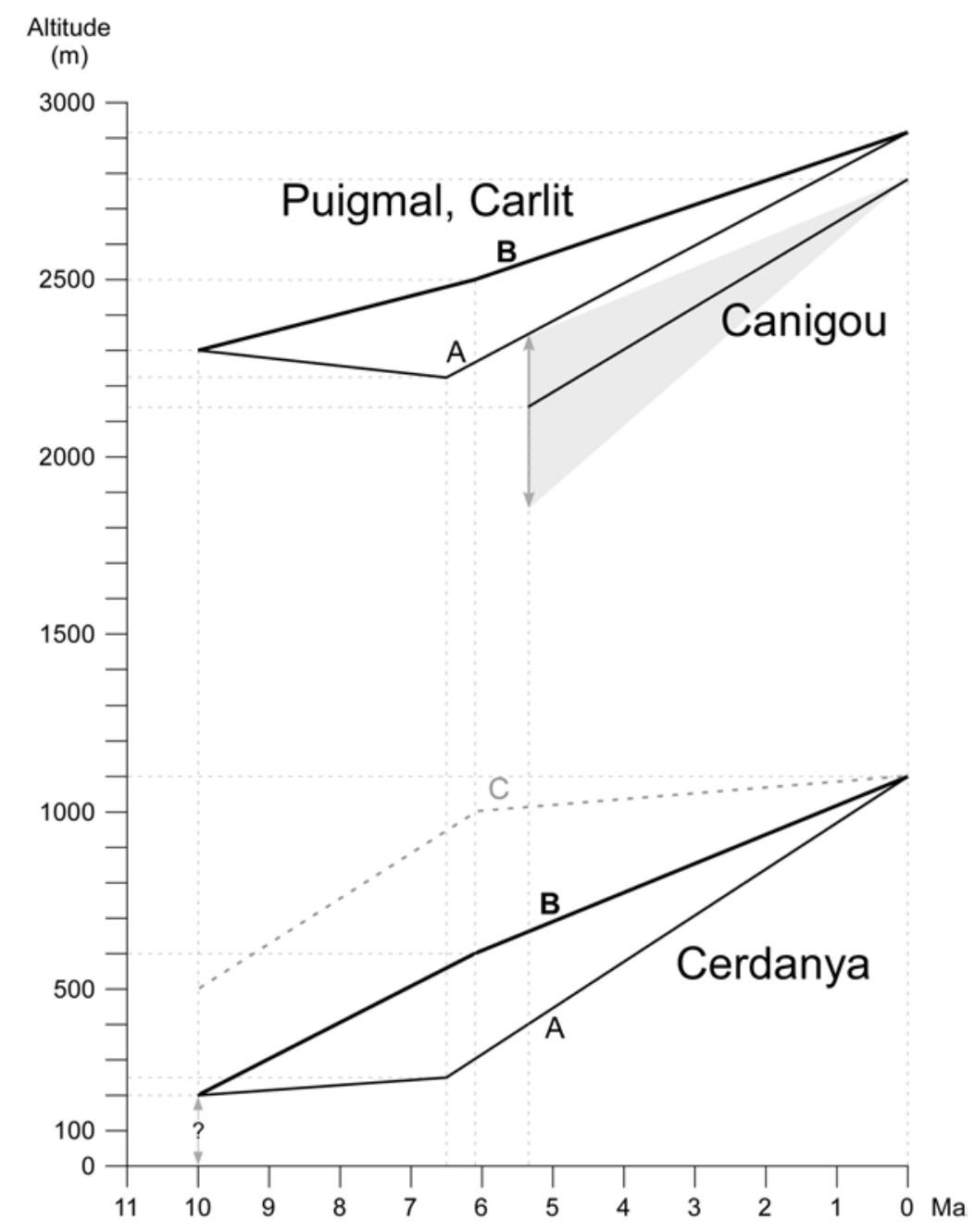

Fig. 8. Optional proposed uplift rates of the Cerdanya Basin, Puigmal and Carlit surrounding massifs, and Canigou Mount between $10 \mathrm{Ma}$ (intermediate point between 11 and 9 Ma) compared and today. Uncertainty ranges are indicated by a double arrow.

A, Option for 6.5 Ma for the top of the Can Vilella section;

B, Preferred option for 6.1 Ma for the top of the Can Vilella section.

C, Option proposed by Agusti et al. (2006), for 6.1 Ma for the top of the Can Vilella section. 


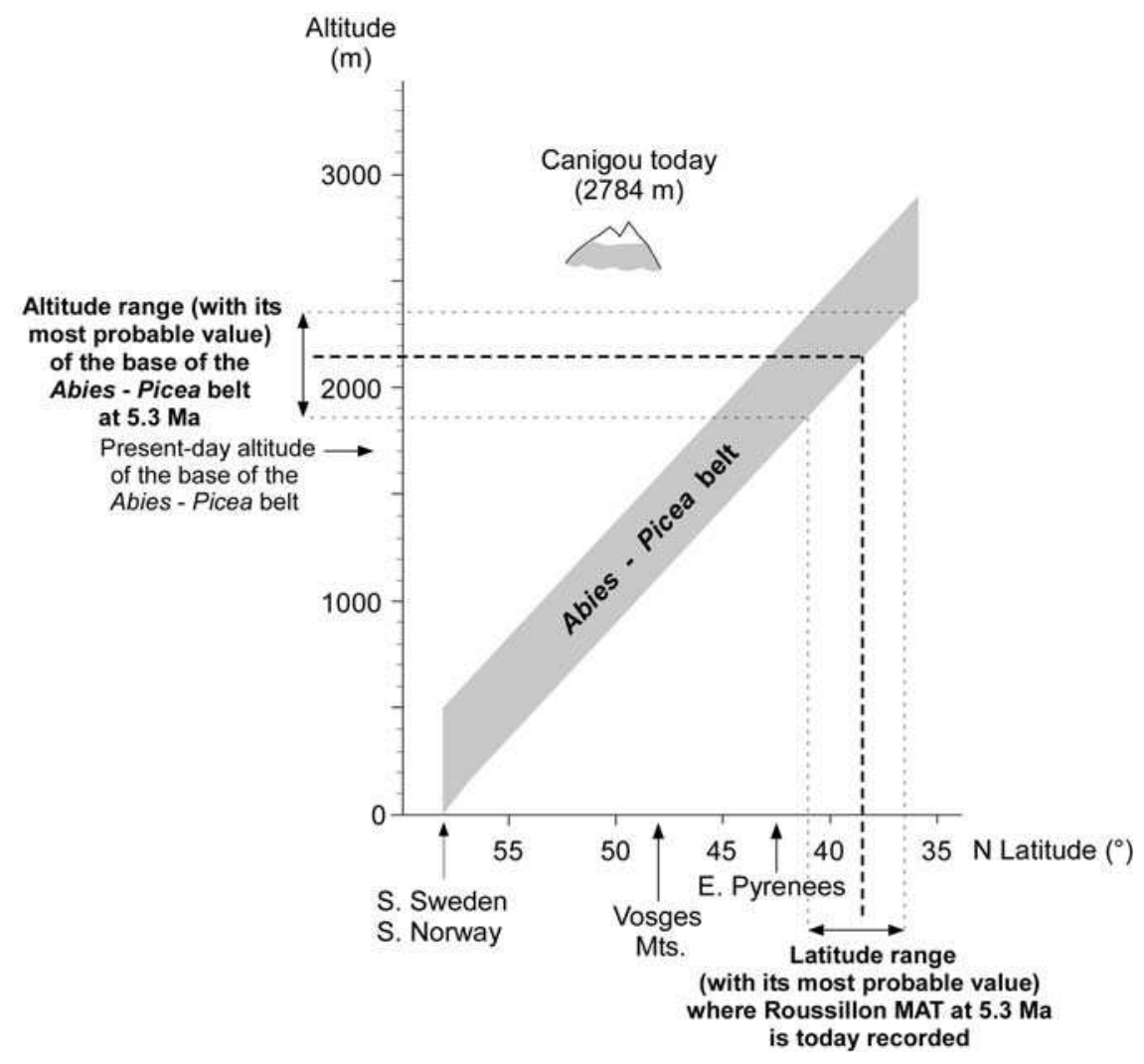

Fig. 9. Altitudinal range of the Abies - Picea belt according to latitude from northern to southern Europe (Ozenda, 1975, 1989). The horizontal bold dashed line: estimated altitude (with its confidence interval: normal horizontal dotted lines) of the base of this ultimate forest belt at the earliest Pliocene with respect to the mean annual temperature (MAT) reconstructed for the Roussillon Basin at that time (vertical bold dashed line: latitude where MLV is today measured; vertical normal dashed lines: latitudinal incertitude rage according to incertitude on MAT). Comparison with the present-day altitude of the Canigou Mount.

\begin{tabular}{|c|c|c|c|c|c|c|c|c|c|c|}
\hline & & LOCALITY & $\begin{array}{c}\text { NORTH } \\
\text { LATITUDE }\end{array}$ & $\begin{array}{c}\text { DIFFERENCE } \\
\text { IN LATITUDE } \\
\text { with locality } 1 \text { or } 4 \text { (DI) }\end{array}$ & \begin{tabular}{|c|} 
DIFFERENCE \\
IN PALAEOLATITUDE \\
with locality 1 or 4 (DI)
\end{tabular} & $\begin{array}{l}\text { MAT ( } \\
\text { Min. }\end{array}$ & $\begin{array}{l}\left.{ }^{\circ} \mathrm{C}\right)=\mathrm{t} \\
\mathrm{MLV}\end{array}$ & $\begin{array}{l}t_{1} \text { or } t_{2} \\
\text { Max. }\end{array}$ & $\begin{array}{l}\mathrm{t}_{3}\left({ }^{\circ} \mathrm{C}\right) \\
\mathrm{MLV}\end{array}$ & $\begin{array}{c}\text { PALAEOELEVATION } \\
(\mathrm{Pe})(\mathrm{m})\end{array}$ \\
\hline $\begin{array}{l}\mathrm{E} \\
\mathrm{A} \\
\mathrm{R} \\
\mathrm{L} \\
\mathrm{Y}\end{array}$ & 6 & Capodarso & $37^{\circ} 33^{\prime}$ & $4^{\circ} 47^{\prime} 50^{\prime \prime}$ & $3.5^{\circ}$ & 15.6 & 22.5 & 24.7 & 20.4 & 600 \\
\hline $\begin{array}{c}M \\
E \\
S \\
S \\
I\end{array}$ & 5 & Douiet 1 & $34^{\circ} 2 ' 25^{\prime \prime}$ & $8^{\circ} 18^{\prime} 25^{\prime \prime}$ & $8.7^{\circ}$ & 21.6 & 23.6 & 24.7 & 18.4 & 250 \\
\hline $\begin{array}{l}\mathrm{N} \\
\mathrm{I} \\
\mathrm{A} \\
\mathrm{N}\end{array}$ & 4 & Can Vilella & $42^{\circ} 20^{\prime} 50^{\prime \prime}$ & & & 15.5 & 17 & 19.8 & & \\
\hline $\begin{array}{l}\mathrm{E} \\
\mathrm{A} \\
\mathrm{R} \\
\mathrm{L} \\
\mathrm{Y}\end{array}$ & 3 & Montredon & $43^{\circ} 11^{\prime}$ & $48^{\prime}$ & $0.74^{\circ}$ & 15 & 17 & 22 & 17.4 & Near sea level \\
\hline $\begin{array}{l}\mathrm{T} \\
\mathrm{O} \\
\mathrm{R} \\
\mathrm{T} \\
0\end{array}$ & 2 & Alborán A1 & $36^{\circ} 38^{\prime}$ & $5^{\circ} 45^{\prime}$ & $4^{\circ}$ & 17 & 20.3 & 25 & 17.9 & 100 \\
\hline $\begin{array}{l}\mathrm{N} \\
\mathrm{I} \\
\mathrm{A} \\
\mathrm{N} \\
\mathrm{N}\end{array}$ & 1 & Sanavastre - Sampsor & $42^{\circ} 23^{\prime}$ & & & 15.5 & 17.4 & 19.8 & & \\
\hline
\end{tabular}

Table 1. Latitude-palaeolatitude and mean annual temperature (MAT) values used for estimating the palaeoelevation of the Cerdanya Basin during the Late Miocene.

MLV, Mean Likely Value. 


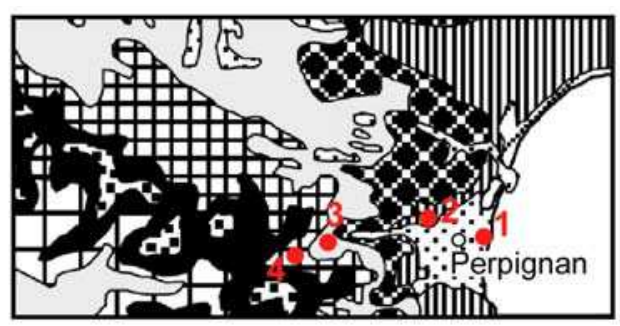

$\because$ Alpine grasslands

Subalpine wood (Pinus cembra)

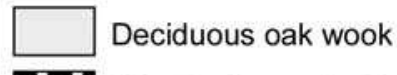

Mixed oak wood with Quercus ilex and Q. pubescens

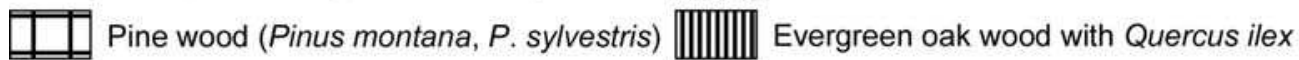

Beech-fir wood

$\because \because$ Alluvial plain (possibly with halophytic coastal ecosystems)

Supplementary data 1. Present-day vegetation map of southern France (Noirfalise et al., 1987) with the modern pollen localities considered (1, Canet - Saint-Nazaire; 2, Ille sur Têt; 3, Mosset; 4, Col de Jau). 


\begin{tabular}{|c|c|c|c|c|}
\hline $\begin{array}{ll}\text { Taxa } & \text { Localities } \\
\end{array}$ & $\begin{array}{l}\text { Canet } \\
\text { Saint- } \\
\text { Nazaire }\end{array}$ & $\begin{array}{c}\text { Ille sur } \\
\text { Têt }\end{array}$ & Mosset & Col de Jau \\
\hline Abies & & 1 & 12 & 12 \\
\hline Larix & & 1 & & \\
\hline Fagus & & 7 & 83 & 74 \\
\hline Betula & 2 & 5 & 108 & 10 \\
\hline Pinus & 27 & 33 & 210 & 22 \\
\hline Cedrus & & 27 & & \\
\hline Taxus & & 3 & & 3 \\
\hline Cupressaceae & 5 & 68 & 3 & \\
\hline Castanea & & 14 & 13 & 5 \\
\hline Juglans & & 1 & 1 & \\
\hline Quercus (deciduous) & 10 & 308 & 24 & 18 \\
\hline Quercus pubescens & 2 & & 28 & 12 \\
\hline Acer & & & & 1 \\
\hline Corylus & & 9 & 74 & 24 \\
\hline Carpinus betulus & & 1 & & 2 \\
\hline Buxus sempervirens & 1 & 1 & 1 & \\
\hline Celtis & & 1 & & \\
\hline Lonicera & & 1 & & \\
\hline Hedera & & 1 & & \\
\hline Sambucus & & 1 & & \\
\hline Tilia & & 1 & & \\
\hline Fraxinus & & 12 & 12 & 2 \\
\hline Fraxinus ornus & & 1 & & \\
\hline Salix & & 1 & 6 & 2 \\
\hline Ulmus & & 1 & & \\
\hline Alnus & 3 & 16 & 14 & 9 \\
\hline Populus & 4 & 5 & 1 & 3 \\
\hline Olea & 2 & 11 & 1 & 2 \\
\hline Pistacia & & 2 & & \\
\hline Pistacia lentiscus & & & 1 & \\
\hline Phillyrea & 1 & & 1 & \\
\hline Quercus ilex type (evergreen) & 12 & & 16 & 4 \\
\hline Ligustrum & & 1 & & \\
\hline Rhamnus & & 1 & & \\
\hline Cistus & & 24 & & \\
\hline Coriaria & & 1 & & \\
\hline Cistus salvifolius & & & 1 & \\
\hline Vitis & & 3 & & \\
\hline Ericaceae & 1 & 52 & 9 & 3 \\
\hline Tamarix & 1 & & & \\
\hline Acacia & & 1 & & \\
\hline Buddleya & & 1 & & \\
\hline Casuarina & & 1 & & \\
\hline Aesculus & & 1 & & \\
\hline Eucalyptus & & 1 & & \\
\hline Ricinus & & 1 & & \\
\hline
\end{tabular}




\begin{tabular}{|c|c|c|c|c|}
\hline Platanus & 1 & 12 & 1 & \\
\hline Asteraceae Asteroideae & 5 & 130 & & 2 \\
\hline Asteraceae Cichorioideae & 51 & 4 & & \\
\hline Artemisia & 1 & 12 & 2 & \\
\hline Ambrosia & & 1 & & \\
\hline Centaurea & & 1 & & \\
\hline Xanthium & & 1 & & \\
\hline Poaceae & 16 & 77 & 15 & 13 \\
\hline Poaceae Cerealia & 3 & 1 & 1 & \\
\hline Cannabaceae & & 1 & & \\
\hline Plantago & 12 & 11 & 4 & 3 \\
\hline Fabaceae Papilionideae & & 14 & & \\
\hline Urticaceae & & 10 & 1 & 1 \\
\hline Mercurialis & & 5 & & \\
\hline Euphorbia & & 2 & & \\
\hline Brassicaceae & 2 & 3 & & 1 \\
\hline Apiaceae & & 2 & 2 & \\
\hline Scrophulariaceae & & & & 1 \\
\hline Crassulaceae & & & 1 & 1 \\
\hline cf. Hypericum & & 1 & & \\
\hline Galium & & 1 & 1 & 1 \\
\hline Helianthemum & & 1 & & \\
\hline Lamiaceae & & 1 & & 2 \\
\hline Polygonum & & 1 & & \\
\hline Rumex & & 1 & 1 & 3 \\
\hline Ranunculaceae & & 1 & 1 & \\
\hline Rosaceae & 6 & 4 & 12 & 7 \\
\hline Cyperaceae & 333 & 3 & & \\
\hline Impatiens & & 1 & & \\
\hline Typha & & 1 & & \\
\hline Potamogeton & & 1 & & 1 \\
\hline Sparganium & & & & 1 \\
\hline Monocotyledons & & 1 & & \\
\hline Amaranthaceae-Chenopodiaceae & 20 & 100 & 1 & \\
\hline Caryophyllaceae & & 9 & & \\
\hline Indeterminate pollen grains & & 4 & & \\
\hline Indeterminable pollen grains & & 46 & & \\
\hline Total of pollen grains & 523 & 2087 & 662 & 245 \\
\hline
\end{tabular}

Supplementary data 2. Present-day pollen analyses at Canet - Saint-Nazaire, Ille sur Têt, Mosset, Col de Jau. 